\title{
Democracy and Social Forces ${ }^{1}$
}

\author{
Michael Bernhard, University of Florida
}

Amanda B. Edgell, University of Gothenburg

New social forces that emerge as part of the process of development are the agents that turn structural change into regime change. Their popular struggles for representation and incorporation occupy a prominent place in our understanding of regime change. Even elitedriven democratic transitions are often thought to necessitate moments of mass mobilization that push liberalization into regime change. Many scholars also contend that after the installation of democracy, an active citizenry leads to democratic stability via more effective government. In contrast, others warn that a mobilized and polarized civil society can undermine democracy particularly if the demands of social forces outstrip the capacity of institutions to process them. In this paper, we explore the role of social organization and mobilization on democracy. The role of social forces on democracy and democratization has until recently been difficult to study in a large-n framework. Comparable cross-national data available for a large number of countries over an extended period of time have, until now, been quite hard to come by, and the influential comparative historical literature on social forces operates according to a radically different ontology than most large-n research. While we cannot track and measure social forces like small$\mathrm{n}$ researchers, we draw upon new measures of civil society organization and mobilization as a proxy. Using the data collected by the Varieties of Democracy (V-Dem) and the Nonviolent and Violent Campaigns and Outcomes (NAVCO) projects, we examine the impact of civil society organizational capacity and protest activity to gauge the extent to which organized and mobilized social forces are responsible for the stability, backsliding, and deepening of democracy.

Popular contention occupies a prominent place in the understanding democratization processes for those who attribute an important role to agency. Further, the role of an active citizenry after the installation of democracy has been posed as one of the factors that leads to democratic stability and greater responsiveness. This paper will begin with a discussion of three different meta-approaches that problematize the role of social forces as central to the origins of democracy and its maintenance. These are the literatures on social force incorporation, the role of

\footnotetext{
${ }^{1}$ Chapter for a planned V-Dem book. Presented at the V-Dem Academic Research Conference, Brastad, Sweden, 23-24 May 2019. This research is supported by the Riksbankens Jubileumsfond (M13-0559:1, PI: Staffan I. Lindberg), the Knut and Alice Wallenberg Foundation (PI: Staffan I. Lindberg), the University of Gothenburg (E 2013/43), and the University of Florida Foundation (PI: Michael Bernhard).
} 
contentious civil society in transitions to democracy, and civil society as the realm of interest articulation in established democracy. The three approaches overlap to some extent with major figures in these debates crossing boundaries and making contributions to multiple literatures.

After this discussion of the three approaches, we explore new possibilities in measuring the impact of social forces on democracy using the Varieties of Democracy (V-Dem) civil society data and resistance campaign data available through the Nonviolent and Violent Campaigns and Outcomes (NAVCO) project. Based on a sample of 158 countries from 1900 to 2015, including over 10,400 observations, we find that both civil society organizational capacity (operationalized as a lagged stock variable) and nonviolent protest campaigns have positive effects on annual changes to democracy across a range of democracy indicators. We also find that rightwing anti-system movements constitute the largest tangible threat to democracy.

\section{Social Forces, Incorporation and Democracy}

The foundational work on social forces and their incorporation focuses on class-based struggles. In the Social Origins of Democracy and Dictatorship, Barrington Moore (1964) concentrates on the strength of the early modern bourgeoisie and how this affected the ways in which the extant rural classes (peasants and landlords) adapted to the commercialization of agriculture. Where the nobility adopted modern commercial methods of farming, as in the United Kingdom, France, and the United States, democracy prevailed. Where feudal methods transformed into labor repressive capitalist practices, the paths of development depended on the position of the bourgeoisie. Where its strength was moderate, like in Germany, fascism emerged. Where it was minimal, as in Russia or China, this resulted in peasant rebellion and communism.

Building on these Moorean foundations, second generation comparative historical analysis placed greater emphasis on the integration of working class formations into competitive 
oligarchic systems. Capitalist development made it dangerous for rulers to ignore concentrated urban populations with shared grievances and low collective action costs. In these accounts, the timing of incorporation and the potential for alliances between social formations are key conditioning variables that determine regime outcomes. O’Donnell (1973) showed how import substitution industrialization provided a conducive material basis for incorporating the middle and working classes into electoral systems with new welfare protections. The subsequent saturation of domestic market demand undermined the material basis of this settlement, and led to subsequent bureaucratic authoritarian episodes where state repression reduced consumption to boost investment and exports. Expanding on O’Donnell, Collier and Collier (1991) also look at the timing of working class incorporation as the prime determinant of regime outcomes across eight Latin American cases.

In Western Europe, Luebbert (1991) concentrates on the outcomes of late nineteenth century struggles over working class incorporation to explain interwar regime outcomes. In the case of early incorporation under liberal hegemony, the logic of the market contained interwar class antagonisms, whereas those who missed this earlier incorporation juncture needed to rely on political containment strategies (social democracy or fascism) during the interwar era. Working class incorporation and the ability of conservative parties to compete electorally also critical for determining whether the ruling class decides to play by the rules of democracy or subvert them (Ziblatt, 2017; Ahmed 2014).

In the most comprehensive geographic treatment using comparative historical analysis, Rueschemeyer, Stephens, and Stephens (1992) explore the links between socioeconomic modernization and democracy. They see democracy as an epiphenomenon of capitalist development, wherein capitalism produces new classes, both working and middle, with new 
interests that are better served by a democratic environment in which to pursue them. In their account they pay attention to these so-called middle sectors, their changing commitments to democracy by time and place, and their capacity to organize.

More recently, distributionist accounts of democratization have carried on in the spirit of the comparative historical school by creating a stylized model of class distributional conflict. In the model, the rich are a potential threat to democracy out of fear of expropriation by lower class revolutionaries (Boix 2003, Acemoglu and Robinson 2006). Using the median voter tipping point of the Meltzer-Richard model (1981), they theorize that situations of low threat to expropriation of the rich (equality, high capital mobility) promote democracy. By contrast, the overthrow of democracy is likely when the poor can use their numeric advantage and threaten to take democratic political control, making threats to expropriate the rich seem credible. Despite the theoretical sophistication of this argument, there is a substantial body of empirical evidence that fails to confirm the theory (Karakoc 2017; Slater, Smith and Nair 2014, Kaufmann and Haggard 2016; Reenock, Bernhard, and Sobek 2007). On the contrary, the most comprehensive test to date finds that income inequality makes transitions to democracy more likely, due to the desire of those who have recently gained wealth to create legal safeguards against expropriation and establish legislative control over taxation (Ansell and Samuels 2014).

While class incorporation dominates discussions, the literature also documents other important incorporation struggles the literature. Paxton (2000) contends that the prevailing operationalizations of democracy disregard the incorporation of women, ignoring one of the principal struggles for equality under the law, and anachronistically pushing the realization of full-blown democracy further back in time. Since her critique, several rich studies documenting women's suffrage struggles or other struggles to put women's concerns on the agenda via 
movements and protests have found their way into the literature (e.g. Murdie and Peksen, 2014; Paxton, Hughes, Green, 2006; Banaszak 1996). Evidence suggests that women's mobilization has helped to initiate political protests and subsequent transitions in a range of cases (Tripp 2001; Waylen 2007). Using novel sequence analysis methods, Wang et al. (2017) shows that the extension of civil liberties to women is essential for democratization.

Others have looked at the incorporation of the ethnic and racial minorities as a component in struggle for democracy. Kopstein and Wittenburg (2010) directly challenge the class incorporation framework used to conceptualize West European and Latin American democratization by showing that ethnic exclusion remained the greatest barrier to democratization in Eastern Europe. Recent work on subnational authoritarianism provides evidence that pockets of ethnic exclusion in the United States delayed the full realization of democracy (Mickey 2015). And Yashar (2005) shows that discrimination against indigenous populations has been a durable barrier to democracy in Latin America.

\section{Civil Society and Democracy}

Rueschemeyer, Stephens, and Stephens (1992) represent a bridge between the older social forces incorporation literature and a newer literature on civil society. In their discussion of class mobilization, they draw attention to the expression of class interests through organizations in an autonomous civil society, which provides new social actors the space and organizational capacity to press their claims vis-à-vis anti-democratic ruling-class actors and the coercive capacities of the state. Their approach is characteristic of the neo-Gramscian approach to the relationship between democracy and civil society. It shares with Gramsci the notion of civil society as a site of contestation between different organized interests and state actors, whether autonomous or 
captured by particular social forces (Migdal 1988). It is an approach that highlights the effect of contentious politics on democratic progress.

\section{Contentious Politics as a Catalyst}

The concept of civil society reemerged in the study of the enfeeblement of the authoritarian regimes in Latin America and Eastern Europe in the late 1970s and early 1980s. Alfred Stepan (1985) and Andrew Arato (1993 [1981]) pioneered its redeployment to make sense of the reemergence of oppositional political organization and challenges to the limits of expression in the public sphere. With the onset of the third wave of democratization, the role of civil society was conceptualized as essential to defeating incumbent efforts to shore up authoritarianism by pushing for democracy and the convoking of free and fair founding elections. In cases where civil society remained passive, authoritarian incumbents were able to maintain themselves in power. Where civil society actors pressed for further change, democratization became possible (Przeworski 1991, O’Donnell and Schmitter 1986, Linz and Stepan 1996).

The neo-Gramscian school echoes those who have stressed the role of contentious politics as an essential component of successful transitions to democracy. Some observers find a strong connection between protest movement strength and successful democratization of authoritarian regimes (Brancati 2016, Haggard and Kaufmann 2016, della Porta 2014). Others look at the coincidence of protest movements and international pressures as essential to democratic breakthroughs in the developing countries and in late-democratizers in the postcommunist world (Beaulieu 2014, Beissinger 2007; Levitsky and Way, 2006; Bunce and Wolchik, 2011). Others using a more historical institutionalist framework stress the timing of contentious mobilization, arguing that protest and pressure by democratic opposition movements 
during critical junctures has a decisive impact on democratic outcomes and the quality of democracy that follows (Bernhard 2016, Bernhard and Jung 2017, Fishman 2017, Fernandes and Branco 2017). Other important work focused on postcommunist politics suggest that civil society can compensate for weaknesses in other democratic arenas such as party systems, thus overcoming democratic deficits (Ekiert and Kubik 1999).

An insurgent civil society can also have a dark side. Kopstein and Chambers (2001) show that authoritarian movements emerge and can persist on the margins of the democratic public space. This constitutes a threat when these anti-democratic movements become more mainstream. Substantial case-based empirical work investigates this phenomenon in the interwar period. Berman (1997) and Riley (2010) find that the capture of civil society organizations by fascist and reactionary movements was an essential pattern of democratic breakdown in several prominent cases like Weimar Germany, Italy, Spain, and Romania.

Despite the rich casework on which these accounts are based, it would be wrong to generally conclude that civil society is a threat to democracy. Studies from the V-Dem project provide ample large-n analysis that the strength of civil society is a much better predictor of democratic survival than breakdown in both the interwar period (Cornell, Skaaning and Moeller 2016) and for the whole of the twentieth century (Bernhard, Hicken, Reenock, and Lindberg 2015). The latter argue that civil society helps to cement democratic settlements by imposing costs on would-be authoritarian defectors.

\section{Civil Society and Organized Interests}

Another influential stream of research that connects civil society with democracy grows out of the literature on political culture. When one digs deeply into the theoretical side of culturecentered arguments, it becomes clear the attitudes underlying this notion of culture grow out of 
behavioral interactions with other citizens in organizations and with the state. Drawing inspiration from Tocqueville's views on how civic activism kept democracy in America from turning into mobocracy, this literature treats the behavioral consequences of participation in civic organizations as crucial for healthy democracy. This neo-Tocquevillian school of thought is more focused on organizational life of existing democracies and how civil society is able to convey its interests to a responsive state. It is a theory of what makes democracy stable rather than embedded in a dynamic theory of regime change.

Beginning with the Civic Culture by Almond and Verba (1963), political scientists have concerned themselves with the political behaviors that create good democratic citizens. The civic culture includes a plurality of citizens who were actively and effectively engaged in politics. Because the notion of culture used here is expansive and includes behavior, it encompasses activism, and thus is akin to theories that explicitly model civil society in terms of citizen organization or activism. The civic culture in turn gave rise to a host of kindred neoTocquevillian studies that come to similar conclusions, that the activist model of citizen engagement has salutary effects for democracy.

Putnam (1994), beginning with Making Democracy Work, argues that civic participation creates social capital and stimulates generalized social trust. A healthy civil society leads to better government and in turn greater support for democracy. Inglehart and Welzel (2005) in Modernization, Cultural Change and Democracy, find that economic modernization leads to systematic shifts in values and culture towards autonomy and equality that makes the spread of democracy globally more likely.

One can read subtle differences within the prominent literature on this subject on how a participatory culture or civil society bolsters democracy. The cultural arguments are more about 
how the values and attitudes of citizens are congruent with democracy. The greater the proportion of citizens that hold those values the easier it is for democracy to function and persist. The social capital argument is more indirect in its causal pathways. Organizational behavior in civil society creates trust which enhances the performance of government institutions, making democracy more effective.

\section{Theoretical Expectations}

The impact of different social forces on democracy and democratization is difficult to study in a large-n framework. Comparable cross-national data for large numbers of countries over time has, until now, been quite hard to come by. In addition, the literature on social forces and democratization operates according to a radically different ontology than most large-n research. Classical comparative historical analysis looks at the process of regime change as slow-accruing and marked by major punctuated events that challenge and change long-term regime equilibria. More recent work relying on the historical institutional variant sees the definitive impact of social forces as highly time dependent. They emerge as important players when the structural constraints posed by path dependence are weakened and purposive action by organized political and social actors has sufficient autonomy to remake institutional arrangements to transform existing structures. Social forces affect democratization by either demanding incorporation into the system of contestation (e.g. struggles for enfranchisement) or by organizing to remove constraints on competition (multipartism, free and fair electoral practices, secret ballot, one person-one vote, other forms of unequal representation like rotten boroughs or gerrymandering) or its prerequisites (e.g. free of speech, and association) (Capoccia and Ziblatt 2010). 
In the literature highlighted above, the preponderance of theory suggests that the impact of the mobilization and incorporation of popular social forces has a salutary effect on democracy. First, the activization of social forces and their struggles for incorporation or liberalization of authoritarian constraints on their ability to contest power is one of the motive forces behind democratization both in comparative historical accounts and actor-centered process models of transition. Second, the behavioral school of political culture has argued that social activism promotes higher levels of generalized social trust and leads to more effective government, thus insulating democracy from the negative effects of poor performance on legitimacy (Lipset 1959, Linz 1978). Therefore, we expect higher levels of social engagement to be correlated with higher democracy scores.

Additionally, the second generation of the school of comparative historical analysis highlighted the importance of different patterns of class alliance in struggles for incorporation, particularly the political choices of working class and middle class actors. In Latin America there has been attention paid to whether middle and working class interests can find common ground in democracy (O'Donnell 1973; Rueschemeyer, Stephens, and Stephens 1991) and in Europe, Luebbert (1991) has shown that the choices of family farmers to make alliances with labor or urban middle class parties had critical ramifications on whether late democratizers took a fascist or social democratic turn in the interwar period. Recent coding of the NAVCO data by Dahlum, Knutsen, and Wig (forthcoming) allow to examine the generalizability of such pathways.

However, there are two threads in the literature that highlight risks for democracy in social activism. Distributionist accounts make the assumption high levels of lower class agitation for political or economic equality, will unsettle the upper classes, and provoke hardline 
responses to prevent democratic transition, and reactionary backlash in existing democracies producing breakdowns. The distributionists in their quest for parsimony perhaps go too far and see all lower mobilization as revolutionary, whereas we know that not all movements that challenge upper class privilege are tactically revolutionary (e.g. aiming for overthrow), and in fact most are reformist and peaceful in nature.

The bad civil society argument follows a logic of equilibrium similar to Huntington (1968). He argues that when popular participation outstrips the institutional capacity of the political system to process demands, the result will be disorder and even regime failure. Whereas some anti-democrats may well fear democracy will replace an orderly society with mob rule, or that some sets of institutions are less suited to respond to an organized citizenry, it hardly seems fair to blame democratic movements for the actions of reactionaries protecting their privileged political status. Despite a few conspicuous examples of mass unrest leading to dictatorship, notably through revolution, greater organizational capacity for excluded social forces tends to promote democracy not only in the long-term, but on balance, even in the short term.

Still, the case evidence presented by authors like Berman (1997) and Riley (2010) and the specification of distributionist models serve as a cautionary tale that the nature of mobilization can be very important. Despite thinking that the nature of the threat is overstated compared to the salutary effect of most forms of social mobilization, it may not be trivial, and certainly ignoring it if it has some basis in reality will not make our models perform better. Thus we think it is important to think about when mobilization could constitute an authoritarian revolutionary threat. In order to capture this dimension of debate, we will try to model our regressions is such a way as to capture those cases where mass mobilization is more likely to threaten democracy. 
Utilizing new data resources, a small literature, inspired by the literature on how violent state birth makes new states more bellicose, has examined how violent and non-violent social mobilization affect long term democratic prospects. Overall, it finds that violent forms of social activism have negative impacts on democracy compared to non-violent forms of action (Teorell 2010, Celestino and Gledistch 2013; Bayer, Bethke, and Lanbach 2016; Bethke and Pikney 2016).

\section{Research Design}

Our theory in this chapter is predicated on a huge literature in comparative historical analysis and historical institutionalism which has investigated the historical emergence of democracy using both Millian comparative methods and process tracing. It is based on a body of evidence of literally hundreds if not thousands of causal process observations. The aim in this chapter is to extend the external validity of this rich body of findings using large- $\mathrm{N}$ correlational methods using a broad sample of 157 countries from 1900 to 2015 . While we cannot track and measure social forces like small-n researchers, Rueschemeyer, Stephens and Stephens (1992) present us with a proxy - civil society. Social forces organize for change and to do so they create civil society organizations, make demands, and organize protests. Thus, reiterating the approach used by Bernhard and Karakoc (2007), we can roughly gauge the impact of social forces by looking at civil society organizational capacity and whether civil society mobilizes for change. We make use of distinct measures of civil society organizational capacity and antisystem movements to gauge the extent to which the emergence and actions of social forces are correlated with enhanced level of democracy.

Two new datasets provide the opportunity to test for the effects of civil society mobilization and organization on democratization by affording researchers substantial time- 
series cross-sectional observations. The first of these, produced by the Varieties of Democracy (V-Dem) Project, provides country-year level measures of a variety of factors affecting democratic regime outcomes utilizing expert coded surveys (Coppedge et al. 2019a). We draw on indicators from its civil society battery to gauge different aspects of its development over extended periods of time. Therefore, our models are unique in their assessment of the effects of civil society both on the basis of mobilization and more routine political action through organization. The second dataset, the Nonviolent and Violent Campaigns and Outcomes (NAVCO) provides multilevel data on major violent and non-violent resistance campaigns (Chenoweth 2011; Chenowith and Stephan 2011). ${ }^{2}$ The data are based on expert consensus. They contain information on the origin and end dates of resistance campaigns, as well as characteristics of the campaign itself. We use these data to assess the effects of distinct episodes of resistance activity.

\section{Measuring Civil Society Organizational Capacity}

Most social science data are measured in discrete time units (typically in a country-year set up). Yet we know that empirically, social science phenomenon unfold across varying time horizons with proximate and distal relationships to other factors. As Gerring, Thacker, and Alfaro $(2012,2)$ note, "regimes do not begin again de novo, with each calendar year. Where one is today depends critically upon where one has been." We suspect that this is particularly the case for organizational capacity. The operation and persistence of civil society organizations over time represents an accumulation of experience, expertise, tactical knowledge, and social

\footnotetext{
${ }^{2}$ We utilize the version 1.1 because it provides greatest coverage (1900-2006).
} 
bonds that accumulate and are enhanced over time in ways that are not captured by short-term observations unique to country-year snapshots.

Therefore, we begin our analysis by treating the organizational capacity of civil society as a stock that fluctuates throughout the history of a polity. Past experience should accumulate over time and embed itself organizationally, but older experience will become less relevant as cadres are replaced by the march of time. As our annual basis for organizational capacity, we utilize the civil society participatory environment indicator found in the V-Dem dataset (v2csprtcpt_osp). Unlike much of the literature, however, we do not assume a constant annual rate of depreciation. ${ }^{3}$ Instead, we theorize that the intensity of past episodes of state repression will accelerate the rate at which the stock of civil society organizational capacity depreciates by demobilizing cadres and disrupting activist networks. To calculate this depreciation rate, we use a V-Dem indicator that gauges government repression of civil society (v2csreprss_osp). As a baseline, we assume that the effects of civil society stock for the first year of one generation are likely to depreciate by the time the next generation attains maturity (i.e. approximately 30 years). As government repression of civil society organizations increases by one ordinal category, we increase the annual depreciation rate by 5 percent. Therefore, we calculate depreciation at $10 \%$ during nonrepressive years, $15 \%$ during weakly repressive years, $20 \%$ during moderately repressive years, $25 \%$ during substantively repressive years, and $30 \%$ during severely repressive years. ${ }^{4}$

To calculate the final stock measure, we use the following formula:

\footnotetext{
${ }^{3}$ For transparency, we do provide estimates with a constant $10 \%$ depreciation rate in Table B3. Our findings are not as robust to this somewhat arbitrary specification of depreciation rates. We contend that the repression-based estimates are a more realistic measure because they allow for a nuanced rate of depreciation that accounts for other underlying regime dynamics.

${ }^{4}$ We use the linear original scale posterior prediction to smooth these estimates. Values fall along a continuum between the discrete categories presented in the original ordinal scales of the V-Dem expert survey and are interpreted as the distance between these thresholds. For more information, see Coppedge et al. (2019b).
} 


$$
\operatorname{CivStock}_{i t}=D_{i t}\left(\sum_{t=1}^{n-1} v 2 \operatorname{csprtcpt\_ osp} p_{i t}\right)
$$

There $D$ is the annual depreciation rate based on government repression of CSOs. Thus, we treat the annual depreciation rate as a weight on the accumulated civil society stock up to the previous year (t-1). We then normalize our measure to fall within a zero to one interval. For our maximum sample of cases, the stock measure ranges from 0.002 to 0.991 , with an average of 0.356. Because of the nature of our dependent variable, we suspect that the relationship between civil society organizational capacity and democracy will be curvilinear. As a country maximizes both, the effects will dissipate. To allow for this, we include a quadratic term for the stock measure. $^{5}$

We draw on the Historical V-Dem data to extend the observations as far back in time as possible but constrain the estimation sample to 1900 or later and only to sovereign country-years. For countries without Historical V-Dem data, we assume that they enter the V-Dem dataset with a tabula rasa, scoring zero on the civil society stock measure during their first year of observation. This is less than ideal, but is limited to a very small number of cases (8). ${ }^{6}$ Because countries in the V-Dem data sometimes experience a gap in coding due to occupation by or governance under another state, we code values based upon the occupying or governing power. This applies to some cases entering the dataset later (e.g. Croatia as Yugoslavia up to 1990) and cases with gaps in coding (e.g. Austria during German occupation from 1938-1944). In the

\footnotetext{
${ }^{5}$ Information criteria supported the use of a quadratic term. We provide results when using the level form of this variable in Table B2.

${ }^{6}$ We provide details on which countries enter the models with fewer than a generation (30 years) of accumulated stock and present robustness checks omitting these country-years from the analysis (see Table A2, Figure A5, and Table B4).
} 
appendix, we provide a list of cases we have assigned in this way (Table A1). The appendix also provides an illustration of how this measure works theoretically and using empirical examples.

\section{Measuring Civil Society Mobilization}

We also consider district episodes of civil society mobilization. To do so, we begin with the V-Dem data on anti-system opposition movements, defined as "any movement — peaceful or armed - that is based in the country (not abroad) and is organized in opposition to the current political system (Coppedge et al., 2019b,182).” We measure the strength of anti-system movements based on their general relationship with the regime (v2csantimv_osp). This variable is calculated using point estimates from the measurement model. Individual expert responses are aggregated and then mapped onto the original survey scale in a continuous fashion. Values range from zero (no or very minimal) to four (a high level of anti-system movement activity that poses a real threat to the regime). For our largest sample of cases, anti-system movement strength ranges from 0.027 to 3.979 , with an average score of 1.273 .

We also take into account the disposition of the anti-system movements drawing on the V-Dem variable for anti-system movement character (v2csanmvch). The main models focus specifically on left-wing and right-wing mobilization. This variable is coded based on the proportion of experts who indicated the presence of such movements within the country-year. We assume that more experts will be aware of and code the presence of these movements as their visibility increases. Therefore, this variable is treated as a proxy for their salience. For our largest sample, the average salience of left-wing movements is 0.338 and right-wing movements is 0.160 .

Finally, we draw upon the NAVCO dataset to explore the effects of violent and nonviolent resistance campaigns (Chenowith 2011). This strategy matches closely with models of 
violent and non-violent protest found elsewhere in the literature (e.g. Teorell 2010). The NAVCO project defines a resistance campaign as "a series of observable, continual tactics in pursuit of a political objective (Chenowith and Stephan 2011, p.14).” These campaigns are classified based on their resistance methods, where (non)violence is determined by expert consensus over whether the primary tactics used physically threatened their targets. Because these data provide rich details on the beginning and end dates of the campaigns, we are able to not only estimate the effects of ongoing resistance but also the long-term impacts after a campaign has ended. To do so, we measure the time since entry or since the last campaign ended, taking the natural logarithm to allow for a return to some equilibrium state. This variable is then interacted with variables capturing whether the campaign that most recently ended was violent or non-violent. ${ }^{7}$ We use the recent coding by Dahlum, Knutsen, and Wig (forthcoming) to capture the social character of campaigns to test the generalizations drawn from the literature on the effect of class coalitions on historical democratization.

\section{Measuring Democracy}

For our main dependent variable, we use the V-Dem electoral democracy index, which captures the degree to which the electoral principle of democracy is achieved within the country. This provides for a middle-range definition of democracy capturing many of the elements of participation and contestation outlined by Dahl's (1972) concept of polyarchy. The index is a composite measure of freedom of association (v2x_frassoc_thick), clean elections (v2xel_frefair), freedom of expression (v2x_freexp_thick), elected officials (v2x_elecoff), and

\footnotetext{
${ }^{7}$ Admittedly, this approach sacrifices information for simplicity. However, the number of ongoing anti-system movements in a given year remains small -with a maximum of three for violent anti-system campaigns and two for non-violent campaigns.
} 
suffrage (v2x_suffr). ${ }^{8}$ For the full sample, the electoral democracy score ranges from 0.009 to 0.948 , with an average score of 0.417 .

Because the electoral democracy index includes measures of association (specifically, government repression of civil society), we risk including the same thing on both sides of the equation when estimating the effects of civil society organization capacity. Therefore, we rely on a more minimalist conceptualization of democracy developed by Schumpeter (1941) for all models that include the civil society stock variable. We measure this continuously using a multiplicative index combining indicators for elected executive (v2x_accex), multiparty elections, and free and fair elections (v2xel_frefair). ${ }^{9}$ While this measure is admittedly procedural, it does not include factors directly related to social mobilization such as freedom of association or repression of civil society organizations, allowing us to avert some immediate concerns regarding endogeneity. For robustness, we run additional models using a similar measure of democracy conceptualized by Munck (2009) that also accounts for the level of suffrage (v2x_suffr). Both the Schumpeter and Munck indexes were originally developed by Hegre, Bernhard, and Teorell (2018). For our sample, these indexes range from zero to 0.947 , with an average of 0.344 on the Schumpeter index and 0.323 on the Munck index.

\section{Control Variables}

We balance the desire to avoid omitted variable bias while maintaining a large number of countries for a long time period. The literature shows that regime type tends to co-vary with level of economic development (Boix and Stokes 2003; Lipset 1959; Przeworski and Limongi 1997).

\footnotetext{
${ }^{8}$ These indicators are aggregated using a combination of weighted averaging and five-way multiplicative interactions (Coppedge et al. 2019b; Teorell 2016)..

${ }^{9}$ Multiparty is derived from the normal probability distribution of predictions from principal factor analysis using indicators for multiparty elections ( $v 2 x \_$mulpar), party bans ( 2 psparban), barriers to parties ( 2 psbars), and opposition party autonomy (v2psoppaut). See Hegre, Bernhard, and Teorell (2018).
} 
We control for this using the natural log of gross domestic product per capita. Because changes to regimes may occur during moments of economic crisis (Gasiorowski 1995), we also control for annual percent change in GDP per capita. Both GDP and GDP growth are measured using the Maddison Project (Bolt and van Zanden 2014). Evidence suggests that regimes with access to material rents are less likely to experience change (Smith 2004). We control for this using oil production per capita (Edgell et al. 2017; Ross and Madhavi 2015; Wimmer, Cedarman, and Min 2009).

\section{Estimation Strategy}

The full sample covers 157 sovereign countries from 1900 to 2015, a total of over 10,300 observations. ${ }^{10}$ With country-year data, ordinary least squares regression often produces biased and inconsistent estimates. While there are many ways to approach cross-sectional time-series data, we seek to balance the empirical parsimony and robust inference by employing fixed effects models. We are unable to include a full battery of control variables for the entire time span under analysis. Rather than sacrificing earlier time periods and reducing our sample due to missing data that are systematically based on geopolitical and developmental levels, we opt to control for all country-level factors using fixed intercepts. In addition, because fixed effects models estimate the within country effects, we can be more confident that our results are not driven by endogenous selection effects between countries. ${ }^{11}$ In all models, the main predictors and control variables are lagged by one year to help mitigate against reverse causality. Finally,

\footnotetext{
10 The NAVCO covers the same number of countries but only from 1900 to 2007.

11 This contrasts with population averaged models that estimate the anticipated outcome based on differences between countries with different values on a covariate. With this approach, if some unobserved factor that makes countries more prone to social mobilization also makes those countries more likely to democratize (or autocratize), our comparisons between countries would be biased.
} 
we include country-clustered robust standard errors to account for heteroskedasticity and year fixed-effects to account for temporal dependence.

The results include a mixture of level and change models. We begin with an initial set of models estimating the level of democracy based on civil society organizational capacity.

Thereafter, we focus on annual changes in democracy to better assess the specific causal effects of civil society, anti-system movements, and resistance campaigns. Following the procedure adopted by Teorell (2012), these models include total change, as well as upward and downward movements. Total change is the net difference in democracy score between $t$ and $t-1$. Upward movements include all positive changes, with negative and no change coded as zeros. Similarly, downward movements include all negative changes, with positive and no change coded as zeros. On average, countries within the sample experienced an annual growth of 0.004 to 0.005 in democracy. Because a country's level of democracy is likely to influence the rate at which it experiences changes, we also control for the lagged level of democracy in all change models. ${ }^{12}$

\section{Results}

Civil society organizational capacity

Table 1 reports the main results for our stock measure of civil society organizational capacity. ${ }^{13}$ In general, the models support the neo-Tocquevillian conclusion that active citizen engagement has salutary effects for democracy. Because of the non-linear relationship, predicted margins with 95\% confidence intervals for the level and change models are presented in Figures 1 and 2. As shown in Figure 1, there is a significant positive relationship between civil society

\footnotetext{
${ }^{12}$ Our expectation is that countries with higher levels of democracy will more stable and thus less prone to change generally, not unlike the way in which economists have expected the rate of growth to slow as economic development proceeds (Barro 1998).

${ }^{13}$ The results are similar when using the Munck index for procedural democracy in Table B1.
} 
organizational capacity and level of procedural democracy. For example, all else equal, as a country moves from 0.30 to 0.60 on the civil society stock measure, we see an estimated improvement of 0.206 on the Schumpeter democracy index. ${ }^{14}$ The negative coefficient on the quadratic term estimates a diminishing effect as civil society organizational capacity achieves higher levels. Nevertheless, we do not empirically observe any anticipated downturn from an overactive bad civil society.

Table 1. Civil society organizational capacity and democratization

\begin{tabular}{|c|c|c|c|c|}
\hline & \multicolumn{4}{|c|}{ Schumpeter democracy index } \\
\hline & (1) & (2) & (3) & (4) \\
\hline & Level & $\Delta$ & Upturns & Downturns \\
\hline \multirow[t]{2}{*}{ Civil society } & $1.146 * * *$ & $0.124 * * *$ & $0.137 * * *$ & -0.013 \\
\hline & $(0.114)$ & $(0.022)$ & $(0.021)$ & $(0.010)$ \\
\hline \multirow[t]{2}{*}{ Civil society (sq.) } & $-0.510 * * *$ & $-0.088 * * *$ & $-0.134 * * *$ & $0.046^{* * *}$ \\
\hline & $(0.128)$ & $(0.022)$ & $(0.021)$ & $(0.009)$ \\
\hline \multirow{2}{*}{ GDP per capita (ln) } & $0.059 * * *$ & $0.008 * *$ & 0.004 & $0.004 * *$ \\
\hline & $(0.015)$ & $(0.003)$ & $(0.002)$ & $(0.001)$ \\
\hline \multirow[t]{2}{*}{ GDP growth (\%) } & $0.074 *$ & $0.054 * *$ & 0.014 & $0.040 * * *$ \\
\hline & $(0.035)$ & $(0.020)$ & $(0.015)$ & $(0.008)$ \\
\hline \multirow[t]{2}{*}{ Oil production (per capita) } & $-0.002 *$ & 0.000 & 0.000 & 0.000 \\
\hline & $(0.001)$ & $(0.000)$ & $(0.000)$ & $(0.000)$ \\
\hline \multirow[t]{2}{*}{ Regional diffusion } & $0.404 * * *$ & $0.065 * * *$ & $0.038 * * *$ & $0.028 * *$ \\
\hline & $(0.079)$ & $(0.015)$ & $(0.011)$ & $(0.009)$ \\
\hline \multirow[t]{2}{*}{ Lagged democracy } & & $-0.132 * * *$ & $-0.092 * * *$ & $-0.040 * * *$ \\
\hline & & $(0.012)$ & $(0.009)$ & $(0.006)$ \\
\hline \multirow[t]{2}{*}{ Constant } & $-0.678 * * *$ & $-0.077 *$ & -0.028 & $-0.049 * *$ \\
\hline & $(0.125)$ & $(0.038)$ & $(0.033)$ & $(0.017)$ \\
\hline R2_Overall & 0.747 & 0.052 & 0.045 & 0.036 \\
\hline R2_Within & 0.612 & 0.094 & 0.090 & 0.046 \\
\hline R2_Between & 0.780 & 0.089 & 0.006 & 0.085 \\
\hline $\mathrm{AI} \overline{\mathrm{C}}$ & -12375.962 & -25840.328 & -31012.777 & -36380.659 \\
\hline BIC & -11499.103 & -24956.222 & -30128.671 & -35496.553 \\
\hline Observations & 10371 & 10371 & 10371 & 10371 \\
\hline Countries & 157 & 157 & 157 & 157 \\
\hline
\end{tabular}

Estimated coefficients and country clustered robust standard errors from country and year fixed effects models. All variables are lagged by one year $(\mathrm{t}-1) .{ }^{\wedge} \mathrm{p}<0.10, * \mathrm{p}<0.05, * * \mathrm{p}<0.01, * * * \mathrm{p}<0.001$.

${ }^{14} \mathrm{Chi}^{2}=168.58, \mathrm{p}<0.001$ 


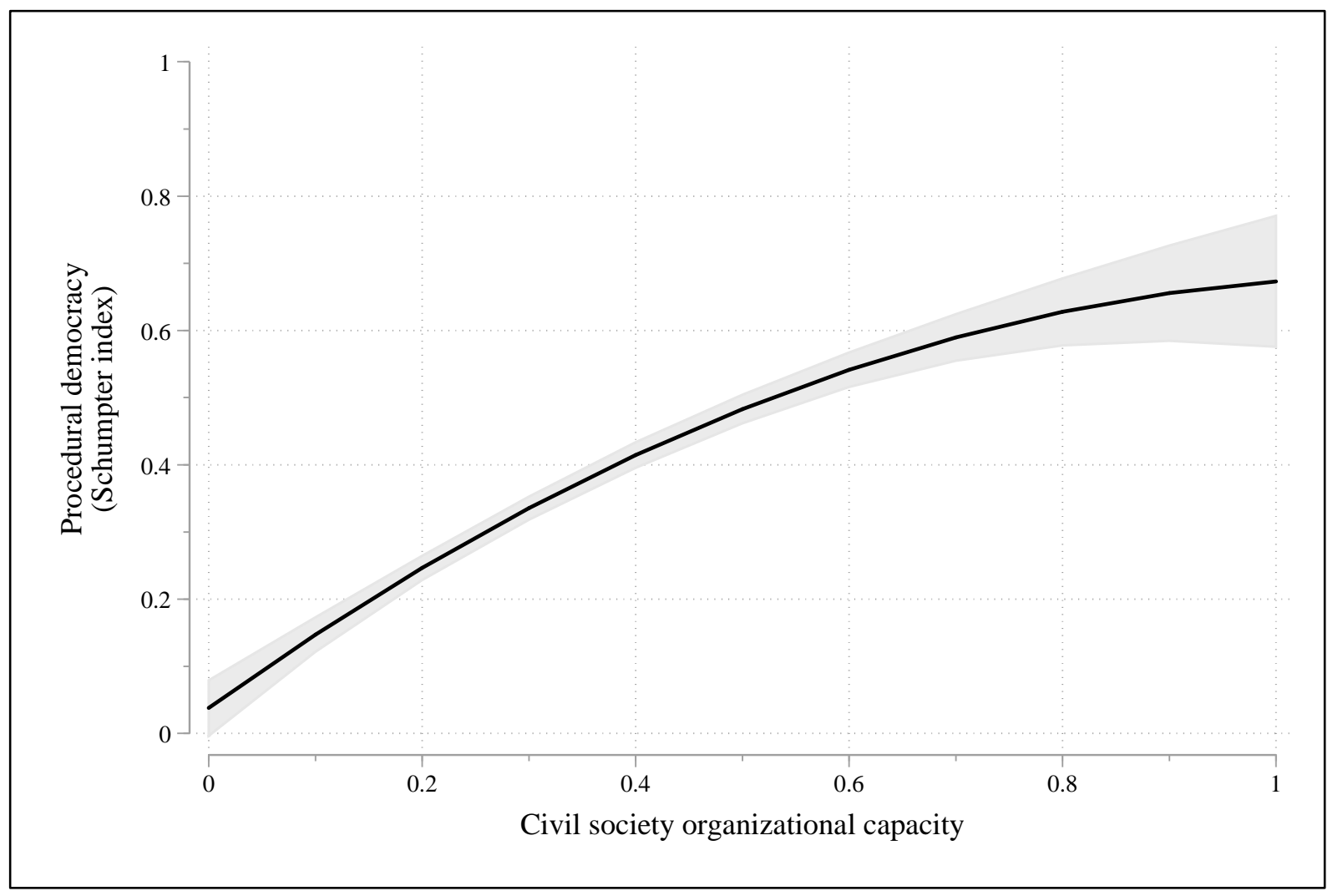

Figure 1. Effects of civil society organizational capacity on procedural democracy. Results plotted include adjusted predicted margins and 95\% confidence intervals based on estimates from Model 1. The outcome variable is measured as the level of procedural democracy based on the Schumpeter Index. Civil society organizational capacity is measured as a stock at $t_{-1}$ with depreciation contingent upon government repression of CSOs.

The results for annual changes in procedural democracy also support theories about the importance of citizen engagement for democratization. All else equal, as a country increases from 0.30 to 0.60 on the civil society stock measure, its estimated annual change on the Schumpeter index moves from 0.007 to $0.021 .^{15}$ Afterward, the effects of additional organizational capacity begin to depreciate. This finding holds when upturns and downturns are analyzed as separate phenomena. As civil society stock increases from zero to 0.50 , annual

\footnotetext{
${ }^{15} \mathrm{Chi}^{2}=14.59, \mathrm{p}<0.001$.
} 
upturns in procedural democracy improve. After about 0.20 on the stock measure, we also see annual downturns becoming less severe.

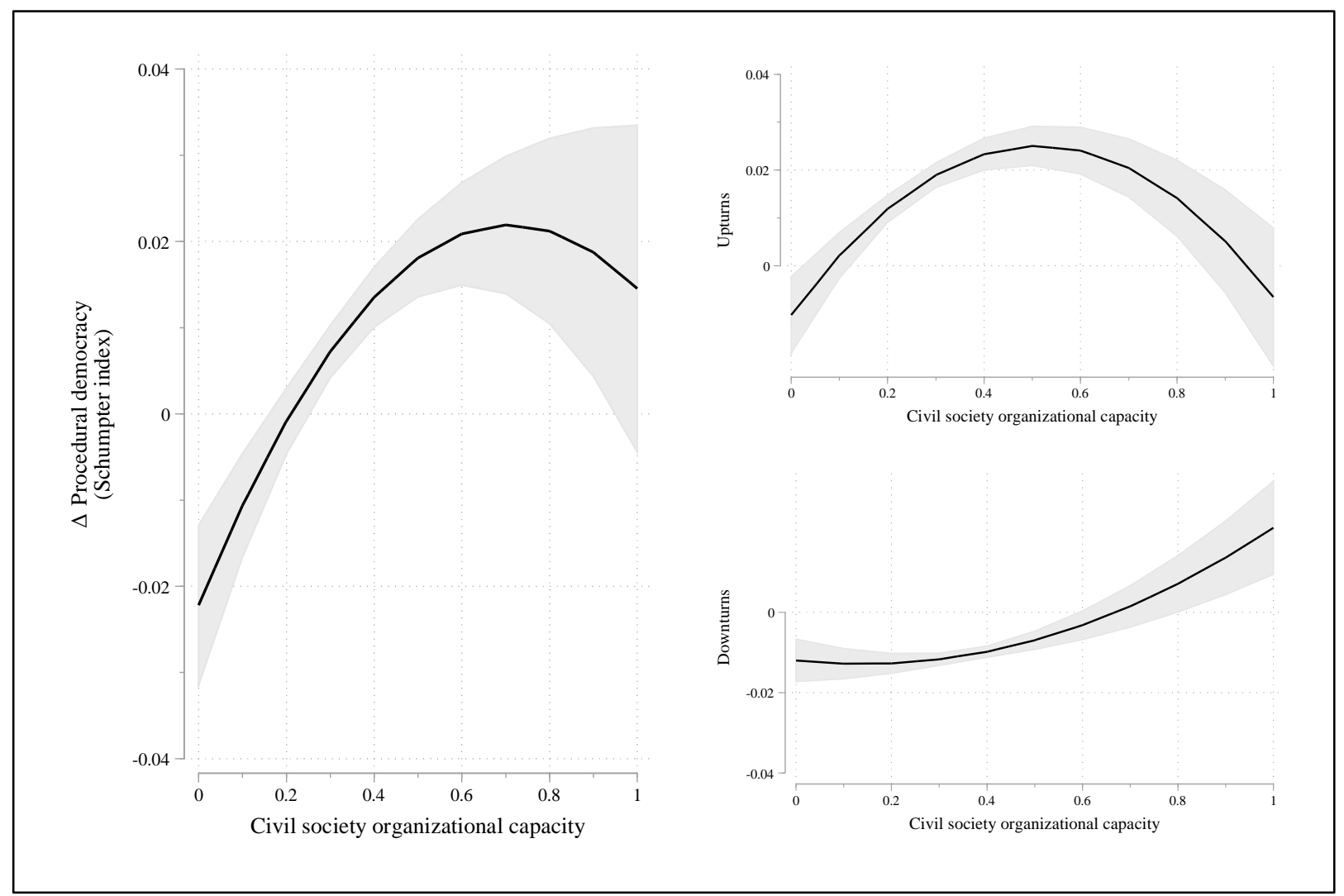

Figure 2. Predicted effect of civil society organizational capacity on rates of democratization. Estimates include adjusted predicted margins and 95\% confidence intervals based on Model 2, Model 3, and Model 4. The outcome variable is measured as the annual change in procedural democracy based on the Schumpeter Index, as well as net annual upturns and downturns. Civil society organizational capacity is measured as a stock at $t_{-1}$ with depreciation contingent upon government repression of CSOs. Note that some values fall outside observable bounds of upward and downward movements.

\section{Civil society anti-system mobilization using V-Dem}

Table 2 reports the results for models estimating the relationship between the V-Dem measure of anti-system movement strength and annual changes to democracy. In general, Model 5 and Model 8 do not show that anti-system movements significantly correlate with annual changes in electoral or procedural democracy. However, when we separate the distinct causal 
Table 2. Anti-system movements and democratization

\begin{tabular}{|c|c|c|c|c|c|c|}
\hline & \multicolumn{3}{|c|}{ Electoral democracy index } & \multicolumn{3}{|c|}{ Schumpeter democracy index } \\
\hline & $(5)$ & (6) & (7) & $(8)$ & $(9)$ & (10) \\
\hline & $\Delta$ & Upturns & Downturns & $\Delta$ & Upturns & Downturns \\
\hline \multirow[t]{2}{*}{ Anti-system movement strength } & -0.001 & $0.004 * * *$ & $-0.005 * * *$ & -0.001 & $0.004 * * *$ & $-0.005 * * *$ \\
\hline & $(0.001)$ & $(0.001)$ & $(0.001)$ & $(0.002)$ & $(0.001)$ & $(0.001)$ \\
\hline \multirow{2}{*}{ GDP per capita (ln) } & $0.003^{\wedge}$ & 0.001 & $0.002 *$ & $0.008 * *$ & 0.004 & $0.004^{*}$ \\
\hline & $(0.002)$ & $(0.002)$ & $(0.001)$ & $(0.003)$ & $(0.003)$ & $(0.001)$ \\
\hline \multirow[t]{2}{*}{ GDP growth $(\%)$} & $0.034 * * *$ & 0.010 & $0.024 * * *$ & $0.054 * *$ & 0.018 & $0.036 * * *$ \\
\hline & $(0.010)$ & $(0.007)$ & $(0.005)$ & $(0.020)$ & $(0.015)$ & $(0.008)$ \\
\hline \multirow[t]{2}{*}{ Oil production (per capita) } & 0.000 & 0.000 & 0.000 & 0.000 & 0.000 & 0.000 \\
\hline & $(0.000)$ & $(0.000)$ & $(0.000)$ & $(0.000)$ & $(0.000)$ & $(0.000)$ \\
\hline \multirow[t]{2}{*}{ Regional diffusion } & $0.052 * * *$ & $0.026^{*}$ & $0.026 * * *$ & $0.079 * * *$ & $0.046 * * *$ & $0.033 * * *$ \\
\hline & $(0.013)$ & $(0.010)$ & $(0.006)$ & $(0.016)$ & $(0.012)$ & $(0.009)$ \\
\hline \multirow[t]{2}{*}{ Lagged democracy } & $-0.068 * * *$ & $-0.043 * * *$ & $-0.025 * * *$ & $-0.107 * * *$ & $-0.071 * * *$ & $-0.036^{* * *}$ \\
\hline & $(0.007)$ & $(0.006)$ & $(0.003)$ & $(0.011)$ & $(0.008)$ & $(0.005)$ \\
\hline \multirow[t]{2}{*}{ Constant } & -0.027 & -0.002 & $-0.025 *$ & -0.051 & -0.013 & $-0.038 *$ \\
\hline & $(0.017)$ & $(0.014)$ & $(0.011)$ & $(0.036)$ & $(0.032)$ & $(0.018)$ \\
\hline R2_Overall & 0.046 & 0.047 & 0.045 & 0.043 & 0.036 & 0.037 \\
\hline R2_Within & 0.080 & 0.083 & 0.057 & 0.087 & 0.079 & 0.048 \\
\hline R2_Between & 0.118 & 0.021 & 0.098 & 0.113 & 0.065 & 0.044 \\
\hline $\mathrm{AIC}$ & -35187.275 & -40293.284 & -47667.840 & -25758.924 & -30889.126 & -36408.566 \\
\hline BIC & -34310.416 & -39416.425 & -46790.981 & -24882.065 & -30012.267 & -35538.954 \\
\hline Observations & 10371 & 10371 & 10371 & 10371 & 10371 & 10371 \\
\hline Countries & 157 & 157 & 157 & 157 & 157 & 157 \\
\hline
\end{tabular}

Estimated coefficients and country clustered robust standard errors from country and year fixed effects models. All variables are lagged by one year (t-1). $\wedge^{\wedge}<0.10, * \mathrm{p}<0.05, * * \mathrm{p}<0.01, * * * \mathrm{p}<0.001$ 
processes behind democratic growth and decline, the results indicate that as anti-system movements gather strength, regimes are prone to greater change. That is to say, when there is either upward or downward movement in the level of democracy, it is intensified by the presence of stronger anti-system movements. All else equal, Models 6 and 7 estimate that a one-point increase on the anti-system movement scale is associated with 0.004 to 0.005 change in both upward and downward annual movements in electoral democracy. The effect is similar for procedural democracy (Models 9 and 10). ${ }^{16}$ In other words, democratization and autocratization processes seem to both be intensified when stronger anti-system movements are in play. Additionally, the negative sign on the lagged level of democracy scores indicates that more democratic observations are more stable than authoritarian ones. This suggests that the context and character of these movements affect how they influence democratic (and autocratic) regime change.

Because the previous models indicate that the regime context (whether the observation is more vs. less democratic) is likely to moderate the effects of anti-system movements, we interact the anti-system movement strength variable with the lagged democracy score. This interaction should tell us whether anti-system mobilization has differential effects depending on both its strength and the existing regime conditions. The results presented in Table 3 suggest that this is the case. In general, the negative interaction terms indicate that rates of democratization associated with anti-system movement activity decline as existing levels of democracy increase. This is shown in Figure 3 using estimated marginal effects for a one-unit

\footnotetext{
${ }^{16}$ See Table B5 for similar results using the Munck index for procedural democracy.
} 
Table 3. Anti-system strength moderated by lagged democracy

\begin{tabular}{lcccccc}
\hline & \multicolumn{3}{c}{ Electoral democracy } & index & \multicolumn{3}{c}{ Schumpeter democracy index } \\
& $(11)$ & $(12)$ & $(13)$ & $(14)$ & $(15)$ & $(16)$ \\
& $\Delta$ & Upturns & Downturns & $\Delta$ & Upturns & Downturns \\
\hline Anti-system movement strength & $0.003^{*}$ & 0.002 & 0.001 & $0.003^{\wedge}$ & $0.003^{\wedge}$ & 0.000 \\
& $(0.001)$ & $(0.001)$ & $(0.001)$ & $(0.002)$ & $(0.002)$ & $(0.001)$ \\
GDP per capita (ln) & 0.002 & 0.001 & 0.001 & $0.007^{*}$ & $0.005^{\wedge}$ & $0.002^{\wedge}$ \\
& $(0.002)$ & $(0.002)$ & $(0.001)$ & $(0.003)$ & $(0.003)$ & $(0.001)$ \\
GDP growth (\%) & $0.034^{* * *}$ & 0.010 & $0.024^{* * *}$ & $0.054^{* *}$ & 0.018 & $0.036^{* * *}$ \\
& $(0.010)$ & $(0.007)$ & $(0.005)$ & $(0.020)$ & $(0.015)$ & $(0.008)$ \\
Oil production (per capita) & 0.000 & 0.000 & 0.000 & 0.000 & 0.000 & 0.000 \\
& $(0.000)$ & $(0.000)$ & $(0.000)$ & $(0.000)$ & $(0.000)$ & $(0.000)$ \\
Regional diffusion & $0.045^{* * *}$ & $0.030^{* *}$ & $0.015^{*}$ & $0.070^{* * *}$ & $0.049^{* * *}$ & $0.021^{*}$ \\
& $(0.013)$ & $(0.011)$ & $(0.006)$ & $(0.016)$ & $(0.013)$ & $(0.008)$ \\
Lagged democracy & $-0.055^{* * *}$ & $-0.050^{* * *}$ & -0.005 & $-0.087^{* * *}$ & $-0.077^{* * *}$ & $-0.011^{*}$ \\
& $(0.008)$ & $(0.008)$ & $(0.004)$ & $(0.013)$ & $(0.011)$ & $(0.005)$ \\
Anti-system * lagged democracy & $-0.010^{* *}$ & $0.005^{\wedge}$ & $-0.016^{* * *}$ & $-0.016^{* *}$ & 0.005 & $-0.021^{* * *}$ \\
& $(0.003)$ & $(0.003)$ & $(0.003)$ & $(0.005)$ & $(0.004)$ & $(0.004)$ \\
Constant & -0.025 & -0.003 & $-0.021^{*}$ & -0.048 & -0.014 & $-0.034^{\wedge}$ \\
& $(0.017)$ & $(0.014)$ & $(0.011)$ & $(0.036)$ & $(0.032)$ & $(0.018)$ \\
R2_Overall & 0.048 & 0.047 & 0.060 & 0.046 & 0.036 & 0.046 \\
R2_Within & 0.081 & 0.083 & 0.069 & 0.089 & 0.079 & 0.059 \\
R2_Between & 0.105 & 0.029 & 0.100 & 0.104 & 0.069 & 0.035 \\
AIC & -35201.304 & -40298.302 & -47789.432 & -25782.062 & -30890.812 & -36523.556 \\
BIC & -34317.198 & -39414.197 & -46905.326 & -24897.956 & -30006.706 & -35639.450 \\
Observations & 10371 & 10371 & 10371 & 10371 & 10371 & 10371 \\
Countries & 157 & 157 & 157 & 157 & 157 & 157 \\
\hline
\end{tabular}

Estimated coefficients and country clustered robust standard errors from country and year fixed effects models. All variables are lagged by one year (t-1). ${ }^{\wedge} \mathrm{p}<0.10, * \mathrm{p}<0.05, * * \mathrm{p}<0.01, * * * \mathrm{p}<0.001$. 
change in anti-system movement strength at various levels of electoral democracy. All else equal, for a country scoring 0.06 or below on the electoral democracy index, there is a significant positive association between anti-system movement strength and annual changes in democracy the following year. However, as levels of democracy rise the impact of increased anti-system mobilization becomes increasingly negative. ${ }^{17}$ After a country attains about 0.53 on the electoral democracy index, strengthening anti-system movements are associated with subsequent net annual declines in democracy.

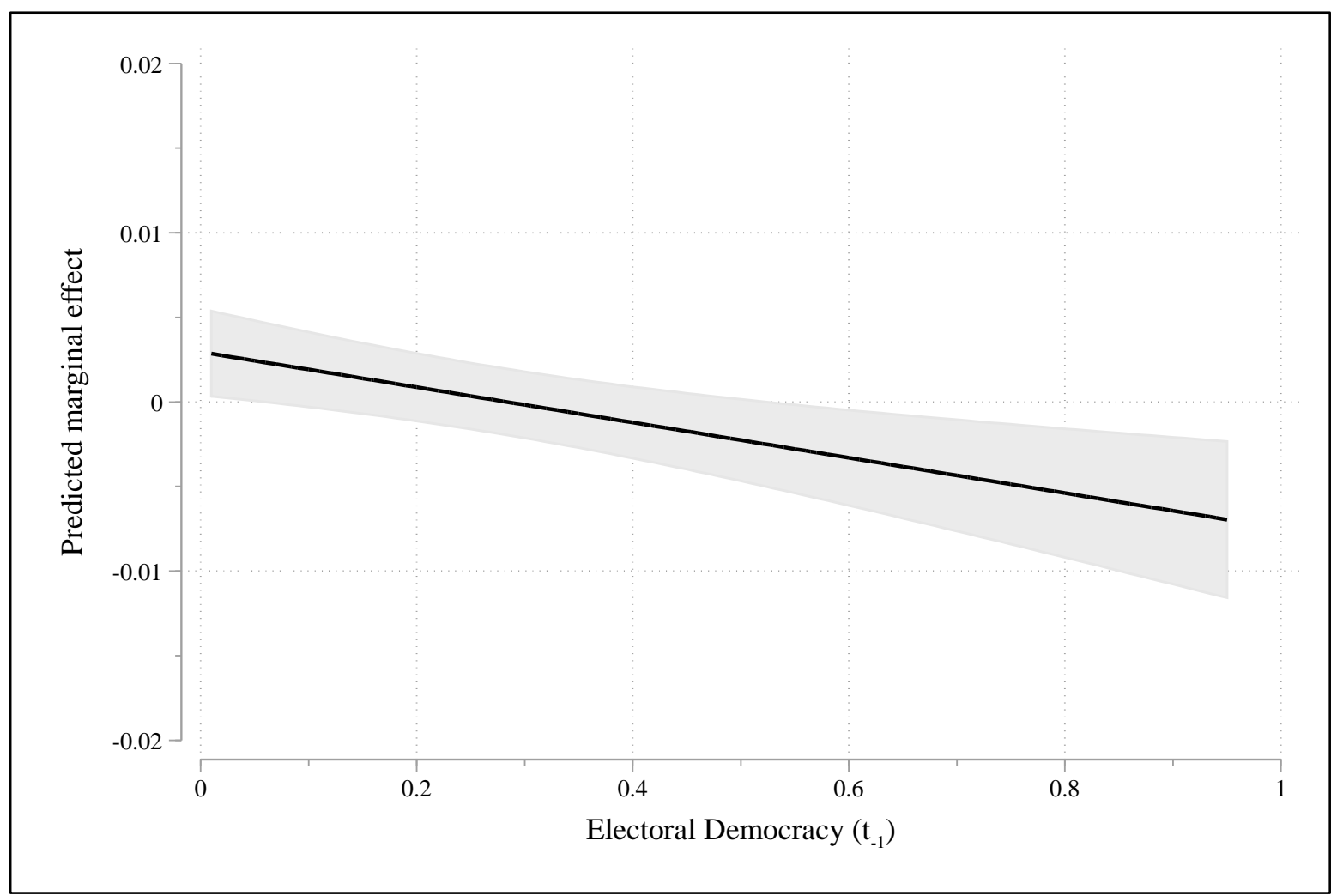

Figure 3. Moderating effects of existing electoral democracy on anti-system movement strength. Results plotted include adjusted predicted marginal effects (dy/dx) and 95\% confidence intervals for a one-unit change in anti-system movement strength at $t_{-1}$ based on varying levels of lagged $\left(t_{-1}\right)$ electoral democracy. The outcome is the annual change in the electoral democracy index based on estimates from Model 11.

\footnotetext{
${ }^{17}$ This finding is similar with the Munck index in table B6. Although the overall change coefficient fails to meet
} standard significance thresholds, the findings for upturns and downturns remain robust. 
We explore the impact of the ideological orientation of anti-system movements using additional measures from the V-Dem civil society data. ${ }^{18}$ Table 4 includes measures of left-wing and right-wing anti-system movements. The results in Model 17 and 20 suggest that the ideological orientation of anti-system movements does not generally explain changes in democracy. Neither the left-wing nor right-wing coefficients are significant for the electoral democracy and Schumpeter democracy indexes. However, in Model 19 we do see that in cases where there are downturns, they become more severe for electoral democracy as the salience of right-wing anti-system movements increases. This finding holds for our measure of procedural democracy, but only at the $92 \%$ confidence level $(\mathrm{p}=0.08) .{ }^{19}$ Meanwhile, our findings for the strength of all anti-system movements remain unchanged. ${ }^{20}$

These findings suggest that if there is a dark side from social mobilization, this is likely to originate from right-wing movements. What role if any does the existing organizational capacity of civil society play in this process? To test for this, models reported in the appendix interact civil society stock with measures of anti-system movements (Table B8). We illustrate the results in Figure 4 using estimated marginal effects (dy/dx). The marginal effects and 95\% confidence intervals show the expected difference in annual changes to procedural democracy as

\footnotetext{
${ }^{18}$ In Table B9, we also report estimates for the effects of ethnic- and religious-based anti-system movements from the V-Dem dataset. The results suggest that there is no general effect from ethnic-based anti-system movements; however, this type of mobilization may reduce the severity of downturns in procedural democracy (as shown in Models B58 and B61). Meanwhile, religious-based mobilization appears to have negative effects on annual rates of democratization, reducing the rates of democratic upturns in particular.

${ }^{19}$ This finding holds with the Munck index in Table B5.

${ }^{20} \mathrm{We}$ run additional tests to see whether there are interactive effects between the strength of anti-system movements and the salience of right- and left-wing mobilization (Table B7). None of these interaction terms are robust at a 95\% confidence level.
} 
Table 4. Anti-system movement character and democratization

\begin{tabular}{|c|c|c|c|c|c|c|}
\hline & \multicolumn{3}{|c|}{ Electoral democracy index } & \multicolumn{3}{|c|}{ Schumpeter democracy index } \\
\hline & $(17)$ & (18) & (19) & $(20)$ & (21) & (22) \\
\hline & $\Delta$ & Upturns & Downturns & $\Delta$ & Upturns & Downturns \\
\hline \multirow[t]{2}{*}{ Left-wing movements } & 0.000 & -0.003 & 0.003 & -0.001 & -0.005 & 0.004 \\
\hline & $(0.004)$ & $(0.003)$ & $(0.002)$ & $(0.007)$ & $(0.006)$ & $(0.003)$ \\
\hline \multirow{2}{*}{ Right-wing movements } & -0.006 & 0.004 & $-0.010 * *$ & -0.002 & 0.008 & $-0.010^{\wedge}$ \\
\hline & $(0.006)$ & $(0.005)$ & $(0.004)$ & $(0.009)$ & $(0.007)$ & $(0.006)$ \\
\hline \multirow[t]{2}{*}{ Anti-system movement strength } & 0.000 & $0.004 * * *$ & $-0.005^{* * *}$ & -0.001 & $0.005 * * *$ & $-0.005 * * *$ \\
\hline & $(0.001)$ & $(0.001)$ & $(0.001)$ & $(0.002)$ & $(0.001)$ & $(0.001)$ \\
\hline \multirow[t]{2}{*}{ GDP per capita (ln) } & $0.003^{\wedge}$ & 0.001 & $0.002 *$ & $0.008 * *$ & 0.004 & $0.004 *$ \\
\hline & $(0.002)$ & $(0.002)$ & $(0.001)$ & $(0.003)$ & $(0.003)$ & $(0.001)$ \\
\hline \multirow[t]{2}{*}{ GDP growth (\%) } & $0.034 * * *$ & 0.010 & $0.024 * * *$ & $0.054 * *$ & 0.019 & $0.035 * * *$ \\
\hline & $(0.010)$ & $(0.007)$ & $(0.004)$ & $(0.020)$ & $(0.015)$ & $(0.008)$ \\
\hline \multirow[t]{2}{*}{ Oil production (per capita) } & 0.000 & 0.000 & 0.000 & 0.000 & 0.000 & 0.000 \\
\hline & $(0.000)$ & $(0.000)$ & $(0.000)$ & $(0.000)$ & $(0.000)$ & $(0.000)$ \\
\hline \multirow[t]{2}{*}{ Regional diffusion } & $0.052 * * *$ & $0.027^{*}$ & $0.025 * * *$ & $0.079 * * *$ & $0.047 * * *$ & $0.032 * * *$ \\
\hline & $(0.013)$ & $(0.011)$ & $(0.006)$ & $(0.016)$ & $(0.012)$ & $(0.009)$ \\
\hline \multirow[t]{2}{*}{ Lagged democracy } & $-0.067 * * *$ & $-0.043 * * *$ & $-0.023 * * *$ & $-0.107 * * *$ & $-0.072 * * *$ & $-0.035 * * *$ \\
\hline & $(0.007)$ & $(0.006)$ & $(0.003)$ & $(0.011)$ & $(0.008)$ & $(0.005)$ \\
\hline \multirow[t]{2}{*}{ Constant } & -0.027 & -0.001 & $-0.025^{*}$ & -0.051 & -0.012 & $-0.038^{*}$ \\
\hline & $(0.017)$ & $(0.014)$ & $(0.011)$ & $(0.037)$ & $(0.033)$ & $(0.018)$ \\
\hline R2_Overall & 0.046 & 0.047 & 0.046 & 0.043 & 0.036 & 0.037 \\
\hline R2_Within & 0.080 & 0.083 & 0.061 & 0.087 & 0.079 & 0.049 \\
\hline R2_Between & 0.116 & 0.018 & 0.096 & 0.113 & 0.059 & 0.044 \\
\hline $\mathrm{AIC}$ & -35186.781 & -40293.986 & -47698.792 & -25755.142 & -30890.476 & -36414.660 \\
\hline BIC & -34295.428 & -39402.634 & -46807.440 & -24863.789 & -29999.124 & -35523.308 \\
\hline Observations & 10371 & 10371 & 10371 & 10371 & 10371 & 10371 \\
\hline Countries & 157 & 157 & 157 & 157 & 157 & 157 \\
\hline
\end{tabular}

Estimated coefficients and country clustered robust standard errors from country and year fixed effects models. All variables are lagged by one year (t-1). ${ }^{\wedge} \mathrm{p}<0.10, * \mathrm{p}<0.05, * * \mathrm{p}<0.01, * * * \mathrm{p}<0.001$. 
the salience of right-wing anti-system movements increases from zero to one at different levels of civil society stock.

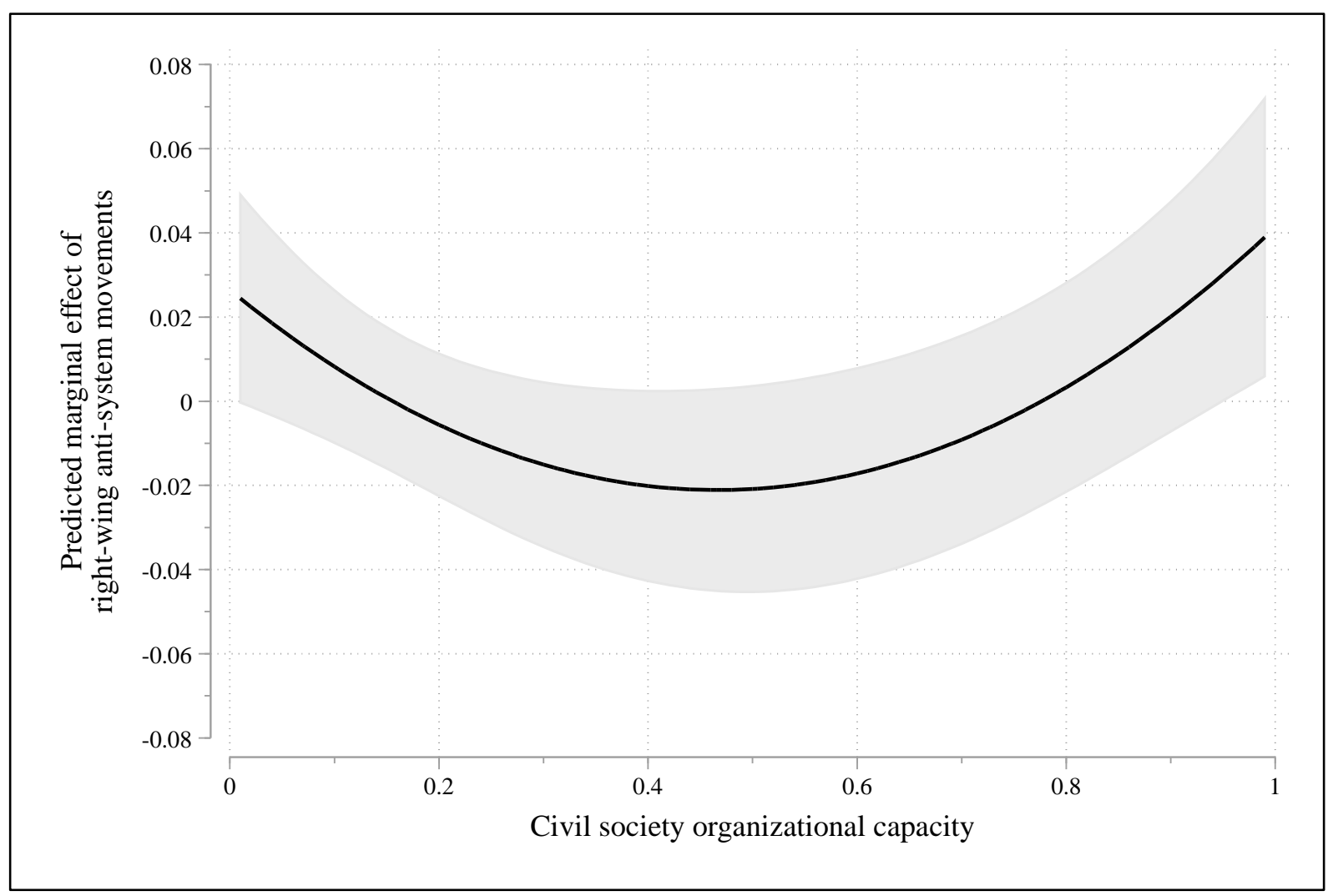

Figure 4. Moderating effects of civil society organizational capacity on right-wing anti-system movements. Results plotted include adjusted predicted marginal effects (dy/dx) and 95\% confidence intervals for an increase from 0 to 1 in right-wing anti-system movement salience at $t_{\text {- }}$ 1 based on varying levels of lagged ( $\left.\mathrm{t}_{-1}\right)$ civil society organizational capacity. The outcome is the annual change in the procedural democracy using the Schumpeter Index based on estimates from Model B47.

While civil society organization capacity may moderate the relationship between antisystem movements and procedural democracy, the effects are fairly modest. The quadratic interaction term predicts that, all else equal, as civil society stock increases from zero to about 0.47, the estimated effect of right-wing anti-system movements on annual changes to procedural democracy is declining. Afterward, the estimated effect of right-wing anti-system movements increases with civil society stock. Nevertheless, $95 \%$ confidence intervals for the effect of rightwing movements fall cross zero when civil society stock is between 0.01 and 0.95 (about $95.51 \%$ 
of the sample). Substantively, this suggests that while the overall moderating effects of civil society stock are significant, differences in annual changes to procedural democracy associated with right-wing anti-system movements could be positive or negative at these values. ${ }^{21}$

\section{Civil society mobilization using NAVCO}

Finally, we report results from models accounting for resistance campaigns and their primary tactics as found in the NAVCO dataset. Table 5 estimates the effects of ongoing violent and non-violent campaigns. ${ }^{22}$ As shown in Model 23 and Model 26, non-violent mobilization during the previous year is associated with significantly higher annual growth in democracy. This finding holds when we consider annual upturns separately in Model 24 and Model 27. Meanwhile, annual downturns in electoral democracy appear to be more severe when the country experienced a violent resistance campaign during the previous year as shown in Model 25. These results are generally reflective of those found in the literature using other measures of violent and non-violent resistance (Teorell 2010). ${ }^{23}$

Perhaps more interesting are the immediate and long-term effects on democratization after a resistance campaign has ended. At the campaign level, Chenowith and Stephan (2011) show that non-violent resistance produces significantly greater democratization five years later.

\footnotetext{
${ }^{21}$ In addition, the estimated marginal effects when civil society stock equals 0.002 , the within-sample minimum, and 0.99 , the within-sample maximum are not significantly different $\left(\mathrm{Chi}^{2}=0.42, \mathrm{p}=0.51\right)$.

${ }^{22}$ See Table B10 for estimates using the Munck measure of procedural democracy.

${ }^{23}$ We also provide estimates using the Cross-National Time-Series dataset, originally developed by Arthur S. Banks (1971) and currently maintained by Databanks International (Banks and Wilson, 2018). While the number of peaceful demonstrations during the previous year are generally associated with democratization (as shown in Table $\mathrm{B} 14)$, the effect is quite small (0.001) and not robust to estimation limited to democratic upturns. Unlike Teorell (2010), we also see some evidence that the number of riots (i.e. violent protests) during the previous year promote annual movement in either direction for electoral democracy (and procedural democracy at the $90 \%$ confidence level). We also replicate the null finding for labor strikes. Given the results from Dahlum, Knutsen, and Wig (forthcoming), this suggests that the effects of general labor strike activity differs markedly from organized labor mobilized against the regime.
} 
Table 5. Violent and non-violent resistance campaigns

\begin{tabular}{lcccccc}
\hline & \multicolumn{3}{c}{ Electoral democracy index } & \multicolumn{3}{c}{ Schumpeter democracy index } \\
& $(23)$ & $(24)$ & $(25)$ & $(26)$ & $(27)$ & $(28)$ \\
& $\Delta$ & Upturns & Downturns & $\Delta$ & Upturns & Downturns \\
\hline Violent campaign & -0.003 & 0.003 & $-0.005^{* * *}$ & -0.001 & 0.002 & $-0.003^{\wedge}$ \\
& $(0.002)$ & $(0.002)$ & $(0.002)$ & $(0.004)$ & $(0.003)$ & $(0.002)$ \\
Nonviolent campaign & $0.036^{* * *}$ & $0.037^{* * *}$ & -0.001 & $0.047^{* * *}$ & $0.049^{* * *}$ & -0.002 \\
& $(0.008)$ & $(0.008)$ & $(0.002)$ & $(0.012)$ & $(0.012)$ & $(0.003)$ \\
GDP per capita (ln) & 0.003 & 0.000 & $0.003^{* * *}$ & $0.009^{* *}$ & 0.005 & $0.004^{* *}$ \\
& $(0.002)$ & $(0.002)$ & $(0.001)$ & $(0.003)$ & $(0.003)$ & $(0.001)$ \\
GDP growth (\%) & $0.034^{* *}$ & 0.008 & $0.026^{* * *}$ & $0.049^{*}$ & 0.011 & $0.038^{* * *}$ \\
& $(0.011)$ & $(0.008)$ & $(0.005)$ & $(0.020)$ & $(0.016)$ & $(0.009)$ \\
Oil production (per capita) & 0.000 & 0.000 & $-0.000^{\wedge}$ & 0.000 & 0.000 & 0.000 \\
& $(0.000)$ & $(0.000)$ & $(0.000)$ & $(0.000)$ & $(0.000)$ & $(0.000)$ \\
Regional diffusion & $0.056^{* * *}$ & $0.033^{* *}$ & $0.024^{* * *}$ & $0.086^{* * *}$ & $0.055^{* * *}$ & $0.031^{* * *}$ \\
& $(0.013)$ & $(0.011)$ & $(0.006)$ & $(0.016)$ & $(0.012)$ & $(0.009)$ \\
Lagged democracy & $-0.060^{* * *}$ & $-0.040^{* * *}$ & $-0.021^{* * *}$ & $-0.103^{* * *}$ & $-0.070^{* * *}$ & $-0.033^{* * *}$ \\
& $(0.007)$ & $(0.006)$ & $(0.003)$ & $(0.012)$ & $(0.009)$ & $(0.005)$ \\
Constant & $-0.031^{\wedge}$ & 0.009 & $-0.040^{* * *}$ & $-0.058^{\wedge}$ & -0.010 & $-0.049 * *$ \\
& $(0.018)$ & $(0.014)$ & $(0.010)$ & $(0.035)$ & $(0.029)$ & $(0.016)$ \\
R2_Overall & 0.062 & 0.069 & 0.031 & 0.054 & 0.050 & 0.033 \\
R2_Within & 0.093 & 0.102 & 0.043 & 0.096 & 0.092 & 0.041 \\
R2_Between & 0.053 & 0.028 & 0.031 & 0.047 & 0.052 & 0.025 \\
AIC & -31419.499 & -35940.306 & -42344.587 & -22827.246 & -27357.666 & -32305.146 \\
BIC & -30606.297 & -35127.104 & -41538.519 & -22014.044 & -26551.598 & -31491.943 \\
Observations & 9259 & 9259 & 9259 & 9259 & 9259 & 9259 \\
Countries & 157 & 157 & 157 & 157 & 157 & 157 \\
\hline
\end{tabular}

Estimated coefficients and country clustered robust standard errors from country and year fixed effects models. All variables are lagged by one year (t-1). ${ }^{\wedge} \mathrm{p}<0.10, * \mathrm{p}<0.05, * * \mathrm{p}<0.01, * * * \mathrm{p}<0.001$. 


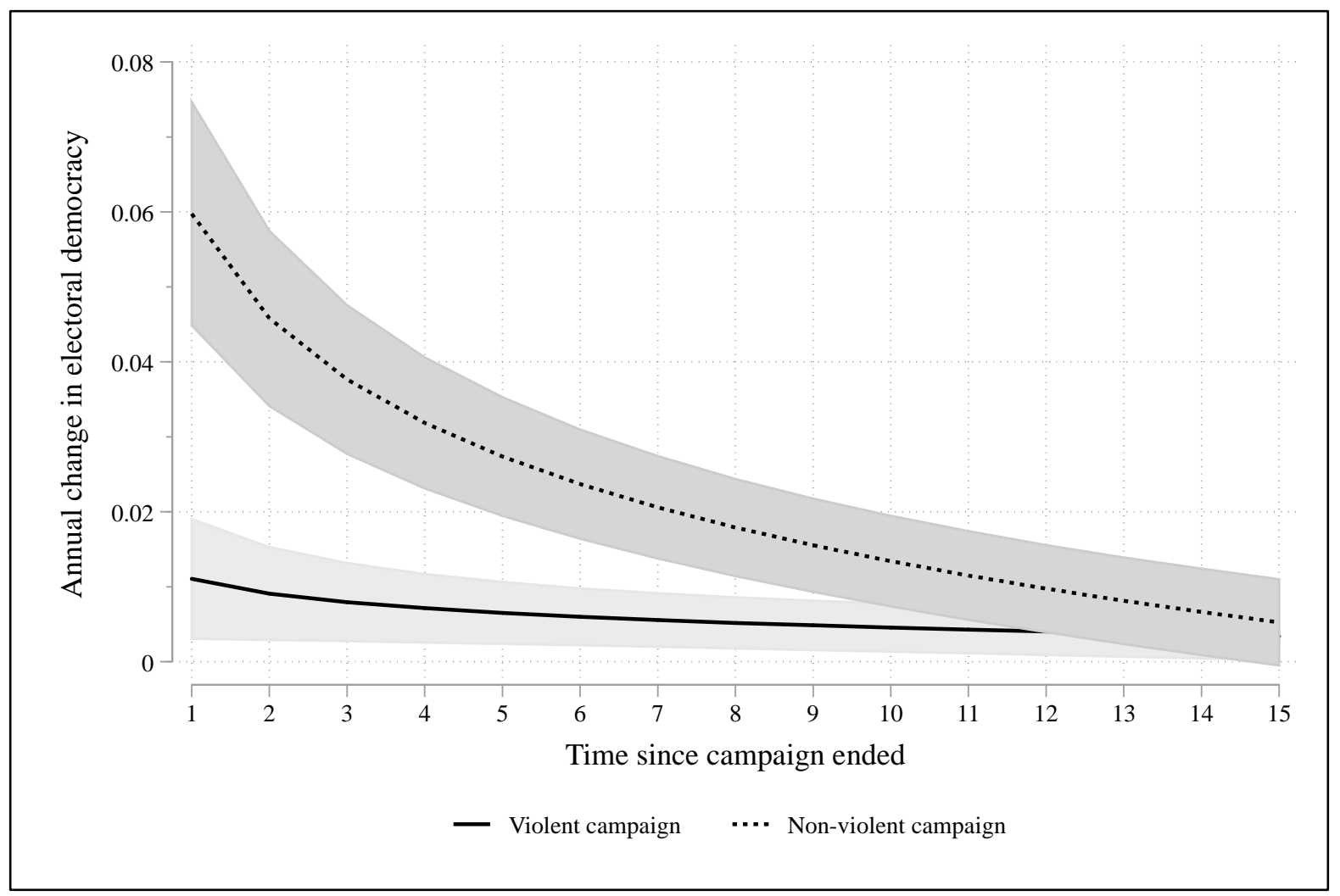

Figure 5. Immediate and long-run effects of violent and nonviolent resistance campaigns on rates of democratization. Results plotted include adjusted predicted margins and $95 \%$ confidence intervals based on estimates from Model B65. The point estimates reflect the expected annual change in electoral democracy based on time since the last resistance campaign ended.

However, their models are limited to the set of cases that experienced a resistance campaign, and thus might be prone to selection effects. Likewise, their models are limited to the effects five years later. Instead, we introduce a series of models in Table B11 that account for long term effects by interacting indicators for the type and amount of time since the most recent campaign ended (or entry if no previous campaign has occurred). Because these models are somewhat difficult to interpret, we present predicted margins and 95\% confidence intervals in Figure 5. All else equal, the year after a violent campaign ends, the estimated annual change in electoral democracy is 0.011 . By contrast, if that same campaign had been non-violent, electoral democracy would have increased by about 0.060 , a significant difference (at $\mathrm{Chi}^{2}=26.31$, $\mathrm{p}<0.001$ ). These effects appear to persist for some time (around 15 years) with diminishing 
magnitude. After about twelve years, we see similar estimated annual changes in democracy for periods after violent and non-violent campaigns.

In the appendix, we report the additional models for the effects of other types of resistance campaigns found in the NAVCO dataset. Drawing on extensive data collection efforts by Dahlum, Knutsen, and Wig (forthcoming), we estimate the associated rates of democratization when social mobilization is dominated by industrial workers, the middle class, peasants, and other sectors of society. The results presented in Table B12 largely replicate these authors earlier work, suggesting that when resistance campaigns are dominated by industrial workers, they have a robust positive effect on rates of democratization. ${ }^{24}$

We also use the Dahlum, Knutsen, and Wig coding to test the general validity of time and space bound theories of class coalition promotion of democratic outcomes. Specifically we address Luebbert's theory (1991) of social democracy as a product of a working class/farmer alliance in interwar Europe, as well as, theories of a middle sector (working and middle class) alliances as a path to democracy in Latin America (O’Donnell 1973; Rueschemeyer, Stephens, and Stephens, 1992). ${ }^{25}$ Our tests provide support for the idea that both of these campaign configurations when concluded promoted positive change in the electoral democracy index, upturns, and mitigate downturns. The results for these models are presented in Table 6 below.

\footnotetext{
${ }^{24}$ The middle class may also contribute to democratic upturns, but with less robust results. Annual downturns in electoral democracy appear to be more severe when peasants dominate resistance movements; however, this finding does not hold for procedural definitions of democracy.

25 To qualify for Luebbert's working class/farmer coalition, the resistance campaign must include industrial workers and peasants, with one of these two groups dominating. To qualify for the middle-sectors thesis, the resistance campaign must include industrial workers and the middle class, with one of these two groups dominating. See appendix for more information on this coding.
} 
Table 6. Resistance campaigns dominated by class coalitions and subsequent democratization using electoral democracy index

\begin{tabular}{|c|c|c|c|c|c|c|}
\hline & \multicolumn{3}{|c|}{ Luebbert (1991) thesis } & \multicolumn{3}{|c|}{ Middle sectors thesis } \\
\hline & (29) & (30) & $(31)$ & $(32)$ & $(33)$ & (34) \\
\hline & $\Delta$ & Upturns & Downturns & $\Delta$ & Upturns & Downturns \\
\hline Industrial workers \& middle class & $\begin{array}{c}0.076 * * \\
(0.023)\end{array}$ & $\begin{array}{c}0.086 * * * \\
(0.022)\end{array}$ & $\begin{array}{l}-0.010 \\
(0.010)\end{array}$ & & & \\
\hline Industrial workers \& peasants & & & & $\begin{array}{c}0.094 * * * \\
(0.019)\end{array}$ & $\begin{array}{c}0.099 * * * \\
(0.018)\end{array}$ & $\begin{array}{l}-0.005 \\
(0.007)\end{array}$ \\
\hline Other campaign ended & $\begin{array}{c}0.030 * * * \\
(0.007)\end{array}$ & $\begin{array}{c}0.033 * * * \\
(0.006)\end{array}$ & $\begin{array}{l}-0.004 \\
(0.002)\end{array}$ & $\begin{array}{c}0.020 * * \\
(0.007)\end{array}$ & $\begin{array}{c}0.024 * * * \\
(0.006)\end{array}$ & $\begin{array}{l}-0.005^{\wedge} \\
(0.003)\end{array}$ \\
\hline Other campaign ongoing & $\begin{array}{l}-0.003 \\
(0.002)\end{array}$ & $\begin{array}{l}0.004^{\wedge} \\
(0.002)\end{array}$ & $\begin{array}{c}-0.007 * * * \\
(0.002)\end{array}$ & $\begin{array}{c}-0.003 \\
(0.002)\end{array}$ & $\begin{array}{l}0.004^{\wedge} \\
(0.002)\end{array}$ & $\begin{array}{c}-0.007 * * * \\
(0.002)\end{array}$ \\
\hline GDP per capita (ln) & $\begin{array}{l}0.004^{\wedge} \\
(0.002)\end{array}$ & $\begin{array}{c}0.001 \\
(0.002)\end{array}$ & $\begin{array}{c}0.003 * * * \\
(0.001)\end{array}$ & $\begin{array}{c}0.004^{\wedge} \\
(0.002)\end{array}$ & $\begin{array}{c}0.001 \\
(0.002)\end{array}$ & $\begin{array}{c}0.003 * * * \\
(0.001)\end{array}$ \\
\hline GDP growth $(\%)$ & $\begin{array}{c}0.031 * * \\
(0.010)\end{array}$ & $\begin{array}{c}0.007 \\
(0.008)\end{array}$ & $\begin{array}{c}0.025 * * * \\
(0.005)\end{array}$ & $\begin{array}{c}0.032 * * \\
(0.010)\end{array}$ & $\begin{array}{c}0.008 \\
(0.008)\end{array}$ & $\begin{array}{c}0.025 * * * \\
(0.005)\end{array}$ \\
\hline Oil production (per capita) & $\begin{array}{c}0.000 \\
(0.000)\end{array}$ & $\begin{array}{c}0.000 \\
(0.000)\end{array}$ & $\begin{array}{c}0.000 \\
(0.000)\end{array}$ & $\begin{array}{c}0.000 \\
(0.000)\end{array}$ & $\begin{array}{c}0.000 \\
(0.000)\end{array}$ & $\begin{array}{c}0.000 \\
(0.000)\end{array}$ \\
\hline Regional diffusion & $\begin{array}{c}0.055 * * * \\
(0.013)\end{array}$ & $\begin{array}{c}0.033 * * \\
(0.011)\end{array}$ & $\begin{array}{c}0.022 * * * \\
(0.006)\end{array}$ & $\begin{array}{c}0.056^{* * * *} \\
(0.013)\end{array}$ & $\begin{array}{c}0.034 * * \\
(0.011)\end{array}$ & $\begin{array}{c}0.022 * * * \\
(0.006)\end{array}$ \\
\hline Lagged democracy & $\begin{array}{c}-0.063 * * * \\
(0.007)\end{array}$ & $\begin{array}{c}-0.042 * * * \\
(0.006)\end{array}$ & $\begin{array}{c}-0.021 * * * \\
(0.003)\end{array}$ & $\begin{array}{c}-0.062 * * * \\
(0.007)\end{array}$ & $\begin{array}{c}-0.041 * * * \\
(0.006)\end{array}$ & $\begin{array}{c}-0.021 * * * \\
(0.003)\end{array}$ \\
\hline Constant & $\begin{array}{l}-0.034^{\wedge} \\
(0.018)\end{array}$ & $\begin{array}{c}0.003 \\
(0.014)\end{array}$ & $\begin{array}{c}-0.037 * * * \\
(0.010)\end{array}$ & $\begin{array}{l}-0.033^{\wedge} \\
(0.018)\end{array}$ & $\begin{array}{c}0.004 \\
(0.014)\end{array}$ & $\begin{array}{c}-0.037 * * * \\
(0.010)\end{array}$ \\
\hline R2_Overall & 0.063 & 0.076 & 0.035 & 0.069 & 0.087 & 0.035 \\
\hline R2_Within & 0.096 & 0.111 & 0.046 & 0.102 & 0.121 & 0.045 \\
\hline R2_Between & 0.074 & 0.060 & 0.022 & 0.067 & 0.046 & 0.022 \\
\hline AIC & -31445.722 & -36040.646 & -42365.123 & -31511.627 & -36137.156 & -42363.368 \\
\hline BIC & -30625.386 & -35220.310 & -41544.787 & -30691.292 & -35316.821 & -41543.032 \\
\hline Observations & 9259 & 9259 & 9259 & 9259 & 9259 & 9259 \\
\hline Countries & 157 & 157 & 157 & 157 & 157 & 157 \\
\hline
\end{tabular}

Estimated coefficients and country clustered robust standard errors from country and year fixed effects models. All variables are lagged by one year ( $\mathrm{t}-1)$, except control for other campaign ongoing. ${ }^{\wedge} \mathrm{p}<0.10,{ }^{*} \mathrm{p}<0.05, * * \mathrm{p}<0.01, * * * \mathrm{p}<0.001$. 
The results show similar effects while these campaigns are ongoing, except for some evidence of short-term contractions in the level of democracy (undoubtedly from short-term repression). ${ }^{26}$

\section{Discussion and Conclusions}

A rich literature contends that social forces play important roles in effecting regime change. The neo-Tocquevillian school contends that civic organization enhances (and is perhaps even essential) to the functioning of democracy. This approach focuses on how associational life fosters positive citizen engagement and bonds of social trust, developing an underlying level of social capital within a society. Meanwhile, neo-Gramscian theories address distinct episodes of political mobilization as crucial elements within episodes of democratization. Periods of mass mobilization pressure regimes to engage in a reforms process that benefits previously excluded groups. Nevertheless, the picture is not always so positive. Scholars have also contended that civil society can sometimes take on an uncivil nature, fomenting violence and triggering episodes of autocratization. In this paper, our approach was to explore whether support exists for these dynamics within a large sample of countries across several generations.

The neo-Tocquevillian argument is perhaps the most challenging to model in such a context. While case-based evidence supports the argument that countries with higher levels of civic engagement tend to have more stable democracies (Putnam 1994), it is also highly likely that the development of social capital is contingent upon associational guarantees that are often embedded within definitions of liberal democracy. Thus, to avoid engaging in tautology, we limited our analysis of the neo-Tocquevillian argument to minimalistic and highly procedural

\footnotetext{
${ }^{26}$ These models are reported in Table B13.
} 
measures of democracy. To proxy social capital, we developed a novel measure of civil society organization capacity conceptualized as a stock that accumulates over time within a polity but depreciates based on state repression. Here we find robust empirical support for the idea that civil society organizational capacity promotes democratic development.

To assess the role of contentious politics, we modeled the effects of anti-system movements as operationalized in the V-Dem data, as well as resistance campaigns measured by the NAVCO project. Our findings suggest that anti-system movements are effective at promoting regime change in both directions, fomenting both democratization and autocratization. Therefore, both the strength and nature of mobilization are important for establishing explanations about how social forces affect democratization. We generally find that more democratic regimes are more stable. Further, we also find that the nature of the existing regime affects the impact of anti-system movements. In democratic polities the presence of anti-system actors tends to be associated with autocratization, whereas in highly authoritarian regimes they are more likely to be associated with democratizing change.

When we turn to the ideological motivations behind anti-system movements, the results indicate that democratic decline is more likely in the face of salient right-wing anti-system movements. This is congruent with the upsurge in far-right extremism and populism, and the current backlash against liberal democracy (Plattner 2019). It is also congruent with an older established line of research that explored the rise of interwar fascist regimes in Europe or bureaucratic authoritarianism in Latin America (Linz and Stepan 1978). Through a series of interaction models, we show that the negative effects of right-wing mobilization are in part moderated by civil society organization capacity. This provides further support for the arguments made by scholarship on the importance of civic engagement for democratic stability. The net 
effect of these tests is to find only some contingent support for bad civil society theories. Rightwing antisystem movements, but not leftwing, constitute an enduring threat to democracy. However, their negative influence is not significantly exacerbated by active civil society. Finally, it also provides limited support for the assumptions of the distributionist school of regime change. Rightwing backlash seems to be the real threat to democracy rather than leftwing mobilization.

This study confirms previous findings about violent and non-violent mobilization. Violent resistance campaigns are associated with more severe democratic declines, and their net negative effects continue to accrue over time for several years. By contrast, non-violent campaigns are associated with immediate and long-term positive changes in democracy. And finally, this study is the first evidence that the findings on specific patterns of class coalition derived from the comparative historical work on regime trajectories in twentieth century Latin America and Interwar Western Europe exhibit a pattern of generalizability across a more global sample. 


\section{References}

Acemoglu, Daron and James Robinson, 2006. Economic Origins of Dictatorship and Democracy. New York, Cambridge University Press.

Ahmed, Amel. 2014. Democracy and the Politics of Electoral System Choice. Cambridge: Cambridge University Press.

Almond, Gabriel A., and Sidney Verba. 1963. The Civic Culture: Political Attitudes and Democracy in Five Nations. Princeton, NJ: Princeton University Press.

Ansell, Ben and David Samuels. 2014. Inequality and Democratization: An Elite-Competition Approach. New York, Cambridge University Press.

Arato, Andrew. 1993 [1981]. "Civil Society and the State, Poland 1980-81," From Neo-Marxism to Democratic Theory. Armonk: M.E. Sharpe. :171-211.

Banaszak, Lee Ann. 1996. Why Movements Succeed Or Fail: Opportunity, Culture, and the Struggle for Woman Suffrage. Cambridge: Cambridge University Press.

Banks, Arthur S. 1971. Cross-polity Time-series Data. Cambridge, MA: MIT Press.

Banks, Arthur S. and Kenneth A. Wilson. 2018. Cross-National Time-Series Data Archive. Databanks International. https://www.cntsdata.com/.

Barro, Robert. 1998. Determinants of Economic Growth. Cambridge, MA: MIT press.

Bayer, Markus, Felix S. Bethke and Daniel Lambach. 2016. "The Democratic Dividend of Nonviolent Resistance," Journal of Peace Research 53(6): 758-761.

Beaulieu, Emily. 2014. Electoral Protest and Democracy in the Developing World. New York: Cambridge University Press.

Beissinger, Mark R. 2007. "Structure and Example in Modular Political Phenomena: The Diffusion of Bulldozer/Rose/Orange/Tulip Revolutions.” Perspectives on Politics 59(2) :259-276.

Berman, Sheri. 1997. "Civil Society and the Collapse of the Weimar Republic," World Politics, 49(3):401-429.

Bernhard, Michael. 2016. “The Moore Thesis: What's Left after 1989?” Democratization 23(1): 118-140.

Bernhard, Michael, Allen Hicken, Christopher Reenock and Staffan I. Lindberg. 2015. "Institutional Subsystems and the Survival of Democracy: Do Political and Civil Society Matter?" Varieties of Democracy Institute: Working Paper No. 4. https://vdem.net/media/filer_public/62/8e/628e4e08-ffb4-45ee-84c5-a25032d1b0dc/vdem_working_paper_2015_4.pdf

Bernhard, Michael and Dong-Joon Jung. 2017. "The Wages of Extrication: Civil Society and Inequality in Postcommunist Eurasia," Comparative Politics 49(3): 373-390. 
Bethke, Felix S. and Jonathan Pinkney. 2016. "Nonviolent Resistance and the Quality of Democracy," Variety of Democracy Institute: Users Working Paper No. 3. https://www.v-dem.net/files/45/Users\%20Working\%20Paper\%203.pdf

Boix, Carles. 2003. Democracy and Redistribution. Cambridge: Cambridge University Press.

Boix, Carles and Susan C. Stokes. 2003. "Endogenous Democratization.” World Politics, 55(4): 517-549.

Bolt, Jutta and Jan Luiten van Zanden. 2014. "The Maddison Project: Collaborative Research on Historical National Accounts.” The Economic History Review, 67 (3): 627-651.

Brancati, Dawn. 2016. Democracy Protests: Origins, Features and Significance. New York: Cambridge University Press.

Bunce, Valerie J. and Sharon L. Wolchik. 2011. Defeating Authoritarian Leaders in Postcommunist Countries. New York, NY: Cambridge University Press.

Capoccia, Giovanni and Daniel Ziblatt. 2010. "The Historical Turn in Democratization Studies: A New Research Agenda for Europe and Beyond," Comparative Political Studies 43(89), 931-968.

Chambers, Simone and Jeffrey Kopstein. 2001. "Bad Civil Society." Political Theory 29(6), 837865.

Chenoweth, Erica. 2011a. "Nonviolent and Violent Campaigns and Outcomes Dataset v.1.1." University of Denver. https://www.du.edu/korbel/sie/research/chenow_navco_data.html.

Chenowith, Erica and Maria J. Stephan. 2011. Why Civil Resistance Works: The Strategic Logic of Nonviolent Conflict. New York: Columbia University Press.

Collier, Ruth Berins and David Collier. 1991. Shaping the Political Arena: Critical Junctures, the Labor Movement, and Regime Dynamics in Latin America. Princeton: Princeton University Press.

Coppedge, Michael, John Gerring, Carl Henrik Knutsen, Staffan I. Lindberg, Jan Teorell, David Altman, Michael Bernhard, M. Steven Fish, Adam Glynn, Allen Hicken, Anna Lührmann, Kyle L. Marquardt, Kelly McMann, Pamela Paxton, Daniel Pemstein, Brigitte Seim, Rachel Sigman, Svend-Erik Skaaning, Jeffrey Staton, Steven Wilson, Agnes Cornell, Lisa Gastaldi, Haakon Gjerløw, Nina Ilchenko, Joshua Krusell, Laura Maxwell, Valeriya Mechkova, Juraj Medzihorsky, Josefine Pernes, Johannes von Römer, Natalia Stepanova, Aksel Sundström, Eitan Tzelgov, Yi-ting Wang, Tore Wig, and Daniel Ziblatt. 2019a. "V-Dem [Country-Year/Country-Date] Dataset v9", Varieties of Democracy (V-Dem) Project. https://doi.org/10.23696/vdemcy19

Coppedge, Michael, John Gerring, Carl Henrik Knutsen, Staffan I. Lindberg, Jan Teorell, David Altman, Michael Bernhard, M. Steven Fish, Adam Glynn, Allen Hicken, Anna Lührmann, Kyle L. Marquardt, Kelly McMann, Pamela Paxton, Daniel Pemstein, Brigitte Seim, Rachel Sigman, Svend-Erik Skaaning, Jeffrey Staton, Agnes Cornell, Lisa 
Gastaldi, Haakon Gjerløw, Valeriya Mechkova, Johannes von Römer, Aksel Sundtröm, Eitan Tzelgov, Luca Uberti, Yi-ting Wang, Tore Wig, and Daniel Ziblatt. 2019b. "VDem Codebook v9". Varieties of Democracy (V-Dem) Project. http://www.v-dem.net.

Cornell, Agnes, Jørgen Møller, and Svend-Erik Skanning. 2016. "Democracy on Retreat: Crisis, State-Society Relations, and the Recurrence of Autocracy in the Interwar Years."

Varieties of Democracy Institute: Working Paper No. 24. https://www.Vdem.net/media/filer_public/3f/c7/3fc7e0f7-edef-43c3-9c07-2d069f8810d6/vdem_working_paper_2016_24.pdf

Dahl, Robert A. 1972. Polyarchy: Participation and Contestation. New Haven, CT: Yale University Press.

Dahlum, Sirianne, Carl Henrik Knutsen, and Tore Wig. Forthcoming. "Who Revolts? Empirically Revisiting the Social Origins of Democracy." Journal of Politics.

Della Porta, Donatella. 2014. Mobilizing for Democracy. Oxford: Oxford University Press.

Edgell, Amanda B., Valeriya Mechkova, David Altman, Michael Bernhard, and Staffan I. Lindberg. "When and Where Do Elections Matter: A Global Test of the Democratization by Elections Hypothesis." Democratization, 24(3): 422-444.

Ekiert, Grzegorz and Jan Kubik. 1999. Rebellious Civil Society. Ann Arbor: University of Michigan Press.

Fernandes, Tiago and Rui Branco. 2017. "Long-Term Effects: Social Revolution and Civil Society in Portugal, 1974-2010," Comparative Politics 49(3), 411-431.

Fishman, Robert. 2017. "How Civil Society Matters in Democratization: Setting the Boundaries of Post-Transition Political Inclusion," Comparative Politics 49(3), 391-409.

Gasiorowski, Mark J. 1995. "Economic Crisis and Political Regime Change: An Event History Analysis." American Political Science Review, 89(4): 882-897.

Gerring, John, Strom C. Thacker, and Rodrigo Alfaro. 2012. "Democracy and Human Development." Journal of Politics, 74(1): 1-17.

Celestino, Mauricio Rivera and Kristian Skrede Gleditsch. 2013. "Fresh Carnations or All Thorn, No Rose? Nonviolent Campaigns and Transitions in Autocracies," Journal of Peace Research 50(3) : 385-400.

Haggard, Stephan and Robert Kaufman. 2016. Dictators and Democrats: Elites, Masses, and Regime Change. Princeton: Princeton University Press.

Hegre, Håvard, Michael Bernhard, and Jan Teorell. 2018. "Reassessing the Democratic Peace: A Novel Test Based on the Varieties of Democracy Data." Varieties of Democracy Institute: Working Paper No. 64. https://www.vdem.net/media/filer_public/f2/9a/f29a60ea-c81e-49e6-a215-d5ac0caa2b02/vdem_working_paper_2018_64.pdf 
Huntington, Samuel P. 1968. Political Order in Changing Societies. New Haven, CT: Yale University Press.

Inglehart, Ronald and Christian Welzel. 2005. Modernization, Cultural Change, and Democracy: The Human Development Sequence. New York, NY: Cambridge University Press.

Karakoç, Ekrem. 2017. “A Theory of Redistribution in New Democracies: Income Disparity in New Democracies in Europe," Comparative Politics 49(3), 311-330.

Kopstein, Jeffrey and Jason Wittenburg. 2010. "Beyond Dictatorship and Democracy: Rethinking National Minority Inclusion and Regime Type in Interwar Eastern Europe." Comparative Political Studies 43(8-9): 1089-1118.

Levitsky, Steven and Lucan A. Way. 2006. "Linkage versus Leverage: Rethinking the International Dimension of Regime Change.” Comparative Politics, 38(4): 379-400.

Linz, Juan. 1978. "Crisis, Breakdown, and Reequilibration," The Breakdown of Democratic Regimes, Juan Linz and Alfred Stepan, eds. Baltimore: The Johns Hopkins University Press. Part I: 1-97.

Linz, Juan and Alfred Stepan, eds. 1978. The Breakdown of Democratic Regimes. Baltimore: The Johns Hopkins University Press.

Linz, Juan J. and Alfred Stepan. 1996. Problems of Democratic Transition and Consolidation. Baltimore, MD: Johns Hopkins University Press.

Lipset, Seymour Martin. 1959. "Some Social Requisites for Democracy: Economic Development and Political Legitimacy.” American Political Science Review, 53(1): 69-105.

Luebbert, Gregory. (1991). Liberalism, Fascism, or Social Democracy: Social Classes and the Political Origin of Regimes in Interwar Europe. Oxford: Oxford University Press.

Meltzer, Allen H. and Scott F. Richard. 1981. "A Rational Theory of the Size of Government," Journal of Political Economy 89(5): 914-927.

Mickey, Robert. 2015. Paths Out of Dixie: The Democratization of Authoritarian Enclaves in America's Deep South, 1944-1972. Princeton, NJ: Princeton University Press.

Migdal, Joel. 1988. Strong Societies, Weak States. Princeton, NJ: Princeton University Press.

Munck, Gerardo L. 2009. Measuring Democracy: A Bridge between Scholarship and Politics. Baltimore, MD: Johns Hopkins University Press.

Murdie, Amanda and Dursun Peksen. 2014. "Women and Contentious Politics: A Global EventData Approach to Understanding Women's Protest." Political Research Quarterly, 68(1): 180-192.

O’Donnell, Gullermo. 1973. Modernization and Bureaucratic-Authoritarianism: Studies in South American Politics. Berkeley: Institute of International Studies, University of California. 
O'Donnell, Guillermo and Phillippe C. Schmitter. 1986. Transitions from Authoritarian Rule: Tentative Conclusions about Uncertain Democracies (vol. 4). Guillermo O'Donnell, Philippe C. Schmitter, and Laurence Whitehead (eds.). Baltimore, MD: Johns Hopkins University Press.

Paxton, Pamela. 2000. "Women's Suffrage in the Measurement of Democracy: Problems of Operationalization." Studies in Comparative International Development 35( 3): 92-111.

Paxton, Pamela, Melanie M. Hughes, and Jennifer L. Green. 2006. "The International Women's Movement and Women's Political Representation, 1893-2003.” American Sociological Review, 71(6): 898-920.

Plattner, Marc F. 2019. "Illiberal Democracy and the Struggle on the Right." Journal of Democracy, 30(1): 5-19.

Przeworski, Adam. 1991. Democracy and the Market: Political and Economic Reforms in Eastern Europe and Latin America. New York, NY: Cambridge University Press.

Przeworski, Adam and Fernando Limongi. 1997. "Modernization: Theories and Facts." World Politics, 49(2): 155-183.

Putnam, Robert A. 1994. Making Democracy Work: Civic Traditions in Modern Italy. Princeton, NJ: Princeton University Press.

Reenock, Christopher, Michael Bernhard, and David Sobek. 2007. "Regressive Socioeconomic Distribution and Democratic Survival," International Studies Quarterly 51(3): 677-699.

Riley, Dylan. 2010. The Civic Foundations of Fascism in Europe: Italy, Spain, and Romania 1870-1945. Baltimore: Johns Hopkins University Press.

Ross, Michael and Paasha Mahdavi. 2015. "Oil and Gas Data, 1932-2014.” Harvard Dataverse. https://doi.org/10.7910/DVN/ZTPW0Y.

Rueschemeyer, Dietrich, Evelene Huber Stephens, and John D. Stephens. 1992. Capitalist Development and Democracy. Chicago: University of Chicago Press.

Schumpeter, Joseph A. 1942. Capitalism, Socialism, and Democracy. Harper \& Brothers.

Slater, Dan, Benjamin Smith, and Gautam Nair. 2014. "Economic Origins of Democratic Breakdown? The Redistributive Model and the Postcolonial State," Perspectives on Politics 12(2): 353-374.

Smith, Benjamin. 2004. "Oil Wealth and Regime Survival in the Developing World, 19601999.” American Journal of Political Science, 48(2): 232-246.

Stepan, Alfred. 1985. "State Power and the Strength of Civil Society in the Southern Cone of Latin America," in Bringing the State Back In, Peter B. Evans, Dietrich Rueschemeyer, and Theda Skocpol, eds. Cambridge: Cambridge University Press. :317-346. 
Teorell, Jan. 2010. Determinants of Democratization: Explaining Regime Change in the World, 1972-2006. New York, NY: Cambridge University Press.

Teorell, Jan, Michael Coppedge, Svend-Erik Skanning, and Staffan I. Lindberg. 2016. "Measuring Electoral Democracy with V-Dem Data: Introducing a New Polyarchy Index." V-Dem Working Papers no.25. Varieties of Democracy Institute. University of Gothenburg.

Tripp, Aili Mari. 2001. "The New Political Activism in Africa." Journal of Democracy 12(3): $141-155$.

Wang, Yi-Ting, Patrick Lindenfors, Aksel Sundström, Fredrik Jansson, Pamela Paxton, and Staffan I. Lindberg. 2017. "Women's rights in democratic transitions: A global sequence analysis, 1900-2012." European Journal of Political Research 56(4): 735-756.

Waylen, Georgina. 2007. Engendering Transitions: Women's Mobilization, Institutions, and Gender Outcomes. Oxford: Oxford University Press.

Wimmer, Andreas, Lars-Erik Cederman, and Brian Min. 2009. "Ethnic Politics and Armed Conflict: A Configurational Analysis of a New Global Data Set." American Sociological Review 74(2): 316-337.

Yashar, Deborah. 2005. Contesting Citizenship in Latin America: The Rise of Indigenous Movements and the Postliberal Challenge. New York: Cambridge.

Ziblatt, Daniel. 2017. Conservative Parties and the Birth of Democracy. Cambridge: Cambridge University Press. 